\title{
THE CHIN ADORNMENT OF THE HIGHLAND LORDS AS A SYMBOL OF HISTORICAL CONTINUITY AND ETHNIC EMBLEM IN THE SOUTHERN ANDES (500-1600 AD) ${ }^{1}$
}

\author{
EL ADORNO DE BARBILLA DE LOS SEÑORES ALTIPLÁNICOS COMO \\ SÍMBOLO DE CONTINUIDAD HISTÓRICA Y EMBLEMA ÉTNICO \\ EN LOS ANDES DEL SUR (500-1600 D.C.)
}

\author{
Helena Horta Tricallotis ${ }^{1}$
}

\begin{abstract}
This work explores the ambit of metal personal insignias or adornments - present in both archaeological evidence and documentary sources- worn by lords in the altiplano over a prolonged period of time which appears to extend from the Middle to the Late period, and even into the Early Colonial. Review of the iconography and comparison with archaeological material in the form of specimens collected in different parts of the Andes provide evidence of the extended use of an Andean system of metal insignias which seem to have denoted both political and religious power simultaneously, through the shared use of these insignias. One of these examples is the insignia in the form of a double -or triple- crescent moon, which the Colla lords are consistently shown wearing throughout the work of Guamán Poma de Ayala. The insignia in question seems to have transferred the power of the huaca (or ancestors) to lords or curacas, in a sort of "corporalisation" and transfer of religious power to the political ambit. This analysis is based on mentions by Ramos Gavilán and Murúa of the use by important altiplano personages of "gold patens on their beards" at the Aucaycusqui Intiraymi festival; this information is significant, since it states expressly that the place where the insignia was worn was "on their beards", which must be understood to mean on the chin as we see in Guamán Poma's drawings. An insignia of very similar form can also be detected in Tiawanaku iconography, which may be considered to be a proto-crescent moon, thus suggesting a possible time-scale for this item. The proposal is based on the triangulation of textual information, material remains and iconographic analysis, delving into the symbolic and temporal scope of this insignia in the altiplano, as well as its possible historical continuity and validity as an ethnic emblem for more than one thousand years.
\end{abstract}

Key words: Pre-Hispanic metal insignias, Bolivian altiplano, identity, historical continuity, illustrated chronicles.

Este trabajo explora en el ámbito de las insignias o adornos personales de metal -tanto en su presencia arqueológica como documental-portados por los señores altiplánicos a través de un prolongado rango temporal que parece abarcar desde el período Medio al Tardío, e incluso hasta el período Colonial Temprano. La revisión iconográfica y su correspondiente contrastación con el material arqueológico de ejemplos recopilados en distintas áreas de los Andes, dan cuenta del extendido uso de un sistema andino de insignias de metal que parece haber denotado simultáneamente tanto al poder político como al religioso, señalándolos por medio del uso compartido de insignias. Uno de estos ejemplos es la insignia en forma de doble -o triple-luna creciente, con la cual son representados los señores collas por Guamán Poma de Ayala de manera muy consistente en toda su obra. La insignia en cuestión parece haber transferido el poder de la huaca a los señores o curacas, en una suerte de "corporalización" y traspaso del poder religioso al político. Este análisis se basa en las menciones de Ramos Gavilán y Murúa acerca del uso por parte de principales altiplánicos de "patenas de oro en la barba" con ocasión de la fiesta Aucaycusqui Intiraymi; este dato no es menor, ya que se dice expresamente que el lugar ocupado por la insignia era en la "barba", esto debe ser entendido como en la barbilla o mentón, tal cual lo vemos en los dibujos de Guamán Poma. Por otra parte, en la iconografía Tiawanaku también se puede detectar una insignia formalmente muy semejante, la que podría ser considerada como una protoluna creciente, estableciendo así la posible profundidad temporal de la misma. La propuesta se basa en el cruce triangulado de la información textual, los restos materiales y el análisis iconográfico, indagando acerca del alcance simbólico y temporal de esta insignia en el altiplano, así como de su posible continuidad histórica y vigencia como emblema étnico por más de mil años.

Palabras claves: insignias prehispánicas de metal, altiplano boliviano, identidad, continuidad histórica, crónicas ilustradas.

1 Instituto de Arqueología y Antropología-San Pedro de Atacama (IAA), Universidad Católica del Norte, Chile. hhorta@ucn.cl 
During earlier research into the use of preInca and Inca insignias (Horta 2008, 2010), I realised the great potential offered by this theme. This is due not only to our good fortune in having access to illustrated chronicles -basically Guamán Poma (1615) and Murúa (1590, 1611) - but also because metal insignias have been conserved in the archaeological record of various sites in the Andes, unlike insignias made of textiles such as the mascapaycha or royal tassel, of which no specimens exist ${ }^{2}$. The metal insignias conserved and known to date fall into two different types: one is the type found on the forehead of the "Niña del Rayo" from Llullaillaco (Argentina; Reinhard and Ceruti 2000) (Figure 1) and the other is the adornment of the Cerro El Plomo child (Figure 2). Both were sacrificed at high altitudes according to the Inca rite of capacocha (Duviols 1976). Various records suggest that the first type of insignia occurred most frequently in the Western Valleys (extreme south of Peru and extreme north of Chile), although there are some records from the highlands 3 ; unfortunately, however, this "tumi insignia" (sensu Horta 2010)

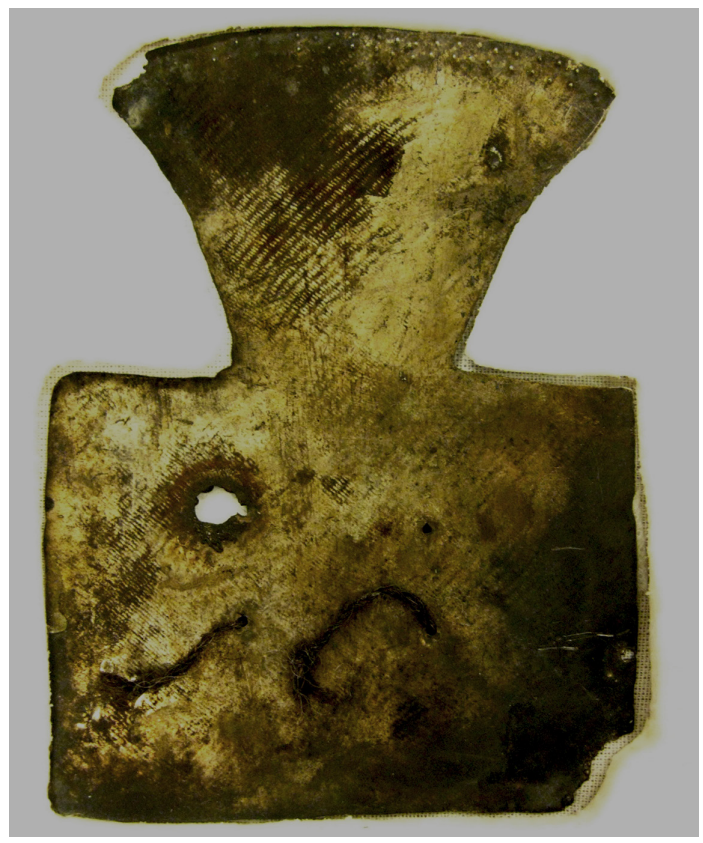

Figure 1. Metal insignia worn on the forehead of the Niña del Rayo in the Llullaillaco capacocha. Museo Arqueológico de Alta Montaña, Salta, Argentina (photograph: author).

Insignia de metal que llevaba en la frente la Niña del Rayo en la capacocha del Llullaillaco. Museo Arqueológico de Alta Montaña, Salta, Argentina (foto de la autora). presents no correlations in the visual chronicles of the 17th century. Thus we have no evidence of its use by any of the ethnic groups, local or macroregional, incorporated into the Tawantinsuyu in the south-central Andes, which might enable us to enter more deeply into its significance and specific ethnic association. A different situation prevails in the case of the adornment of the Cerro El Plomo child, on which we will concentrate in this article.

\section{The Chin Adornment}

This adornment consists of two crescent moon-shaped elements (the upper smaller than the lower), joined by a central bar (Figure 2). As mentioned previously, this is the insignia found with the mummified child from Cerro El Plomo, while another known specimen comes from Lake Titicaca where it was found by Bandelier inside a stone container deposited in the lake waters as an offering (1910: Plate XXXII; here Figure 3) ${ }^{4}$.

Throughout his work, Guamán Poma consistly draws the adornment mentioned here hanging from the neck of the lords of the highlands (Figures 4a-d, 5a-d, 6a-d and 7a-c; see also his Plates 147, 153, $171,250,272,279,295,326,366,368,386,505$, $620,767,794$ and 888). In several of these cases the figures wear both a chin adornment and the chacrahinca $^{5}$ (crescent moon diadem) insignia on the forehead (Figures 4a, 4b, 4c, 5a, 5b, 5c, 5d, 6a, $6 \mathrm{~b}, 6 \mathrm{c}, 7 \mathrm{a}$ and $7 \mathrm{c}$ ) and in the exceptional case of Plates 92 and 1065, the chacrahinca is illustrated on the truncated cone caps, by omitting the chin

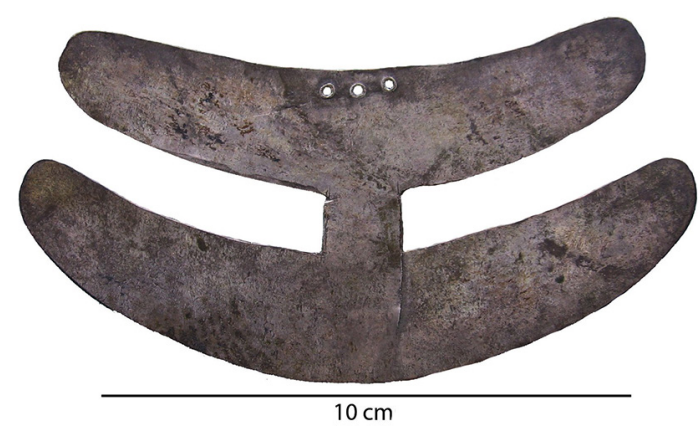

Figure 2. Metal insignia of the Cerro El Plomo Child (taken from Tras la huella del Inca en Chile, exhibition catalogue of Museo Chileno de Arte Precolombino, Santiago).

Insignia de metal del Niño del cerro El Plomo (tomado de Tras la Huella del Inca en Chile, catálogo de exhibición del Museo Chileno de Arte Precolombino, Santiago). 


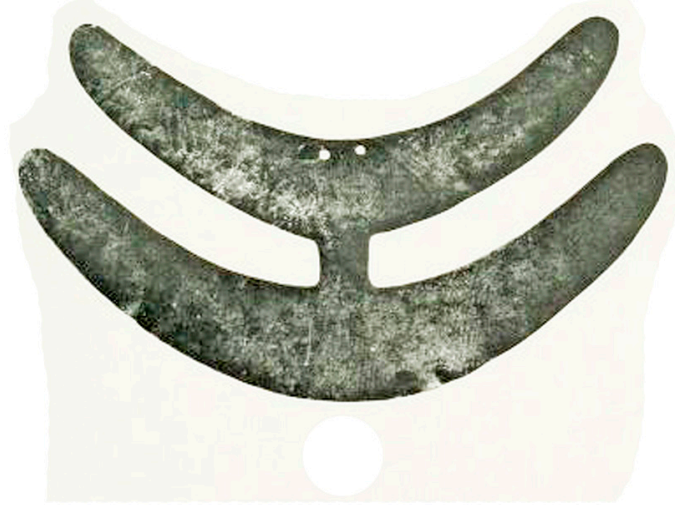

Figure 3. Metal insignia found by A. Bandelier in the Island of the Sun, Lake Titicaca (taken by Bandelier 1910: Plate XXXII.4). Insignia de metal encontrada por A. Bandelier en la Isla del Sol del lago Titicaca (tomado de Bandelier 1910: Plate XXXII.4).

adornment. Murúa, illustrating scenes with highranking altiplano lords, also includes the adornment hanging from the neck (Figure 8), even introducing a variant in which we see three rather than two crescent-shaped elements in order of decreasing size (Figure 9). Thus the chronicles show evidence of adornments with two and three segments. This interesting fact will enable us later to link these colonial images with icons on Tiawanaku ceramics from the Middle period.

The pendant discussed here is not mentioned in Quechua dictionaries, and even more surprisingly, Bertonio does not include it in the words collected in his work. The find of the Cerro El Plomo child, in the Andes above Santiago, Chile, wearing a pendent similar in all respects to those drawn by Guamán Poma, is one of the two archaeological specimens with origin known to date (Mostny 1957). This author offered solid arguments to support her hypothesis of descent from the altiplano -rather than from Cuzco- of the child sacrificed as part of a capacocha; she was also the first to establish an identity link between the metal pendant and the lords of the Bolivian altiplano, based likewise on the chronicler's illustrations.

Another documentary reference which may be adduced with respect to this adornment is a very brief mention by Ramos Gavilán (1976 [1621]), when he described the Inca celebration Intiraymi held in the altiplano by Colla or Aymara individuals: "The indians wore the most curious clothes, and so did the women, and almost all shaved themselves, and the principal people put gold patens on their beards, and all of them went in this manner to the temple of the Sun, to offer their sacrifices" (my emphasis; Ramos Gavilán 1976 [1621]:15).

In this case -as we see from observations in various other contexts- the term paten is used to designate a sheet or plate of variable shape, the principal point of interest being that it is made of metal. Whatever the shape of this adornment, the detail that makes it clear is that the text says expressly that it was worn "on the beard", i.e. the chin, as we see in Guamán Poma's drawings.

Murúa has the following to say of the Intiraymi celebrated in "Potosí and all the Charkas" during the month of June: “....in which they sacrificed one hundred guanaco rams, and they said that this was the festival of the sun, in which they made a large number of carved wooden statues, of quiscuar, all dressed in rich clothing, and they performed the dance which they called cayo, and in the festival they spread many flowers on the way, and the indians came daubed with annatto, and the lords with little gold patens like the canipu on their beards, and all singing..." (my emphasis; Murúa 1962 [1611]).

Both citations speak expressly of an object worn on the beard or chin, hanging from a cord attached to the llautu, as illustrated by Guamán Poma in several of his pictures, for example Plate 888 (Figure 7c). Mostny describes the positon of the adornment worn by the Cerro El Plomo child in similar terms:

Its hair, dark in colour, comes down to below its shoulders and is parted in the centre and arranged in countless fine braids, kept in place by a black cord which goes round the head five times and is secured by another turn passing under the chin (llautu). From the latter hung a silver adornment in the form of two crescents, which is now detached (my emphasis; Mostny 1957:12) (Figure 10 here).

This author, talking of the characteristics of the adornment, says that it is a sheet of silver 2 $\mathrm{mm}$ thick, with three holes in the upper part and dimensions of $12.7 \times 6.8 \mathrm{~cm}$, establishing its original position as follows: 


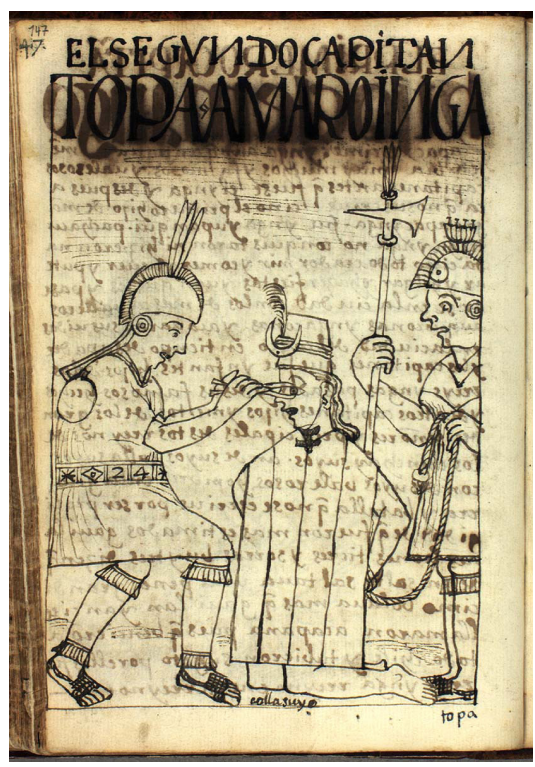

Figure 4a. Drawing 147 of El primer nueva corónica y buen gobierno. The second captain, Tupac Amaru Inka, while punishes a colla lord, who carries truncated conical hat, crescent-shaped diadem and chin adornment.

Lámina 147 de $\mathrm{El}$ primer nueva corónica y buen gobierno. El segundo capitán, Tupac Amaru Inka, mientras castiga a un señor colla, quien porta gorro troncocónico con diadema de medialuna y adorno de barbilla.

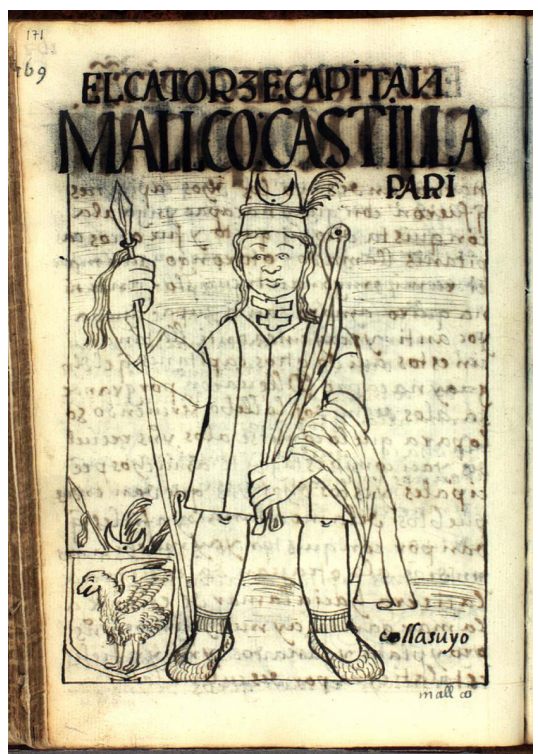

Figure 4c. Drawing 171 of El primer nueva corónica y buen gobierno. The fourteen captain, Mallco Castilla Pari; among the emblems of this colla lord contained the crescent-shaped diadem and the chin adornment.

Lámina 171 de El primer nueva corónica y buen gobierno. El catorce capitán, Mallco Castilla Pari; entre las insignias de este señor colla figuran la diadema de medialuna y el adorno de barbilla.

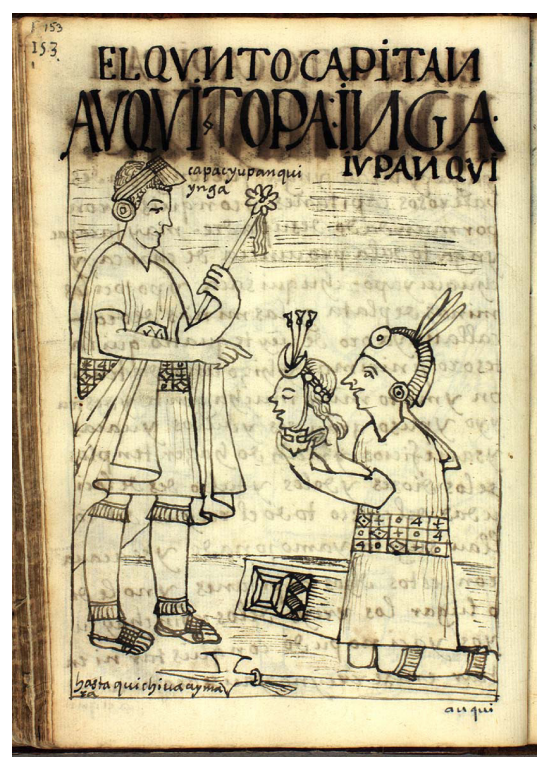

Figure 4b. Drawing 153 of El primer nueva corónica y buen gobierno. The fifth captain, Auqui Topa Inga Yupanqui, presents the severed head of a colla lord; this shows the crescent-shaped diadem and the chin adornment.

Lámina 153 de El primer nueva corónica y buen gobierno. El quinto capitán, Auqui Topa Inga Yupanqui, presenta la cabeza cortada de un señor colla; en ella se aprecia la diadema de medialuna y el adorno de barbilla.

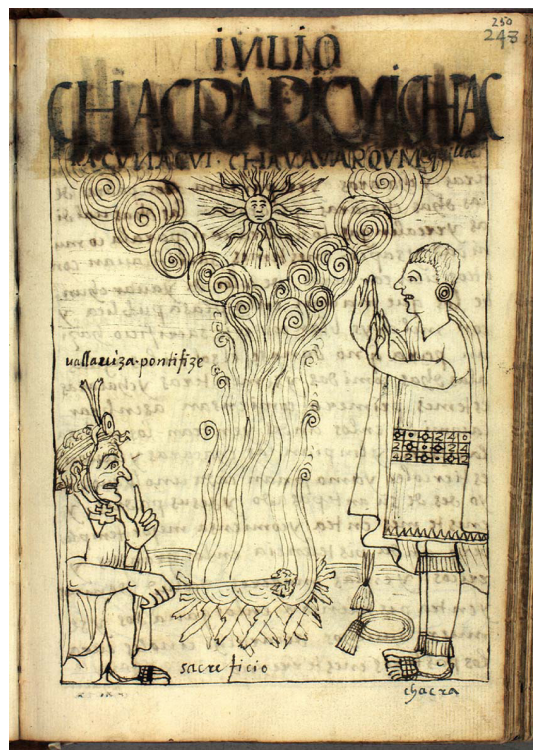

Figure 4d. Drawing 250 of El primer nueva corónica y buen gobierno. This image shows the Inca presenting sacrifice along with the ualla uiza or "pontiff", character who wears the chin adornment.

Lámina 250 de El primer nueva corónica y buen gobierno. En esta imagen se aprecia al Inca presentando sacrificio junto al ualla uiza o "pontífice", personaje que luce el adorno de barbilla. 


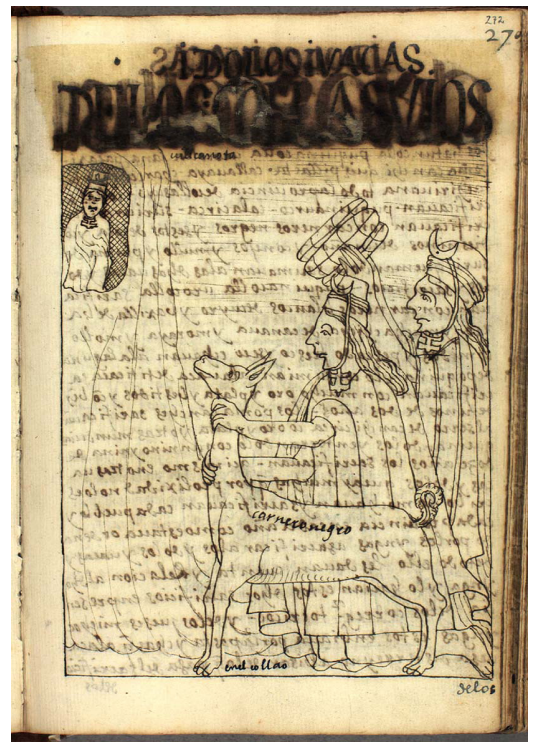

Figure 5a. Drawing 272 of El primer nueva corónica y buen gobierno. Idols and waqas of the Qullasuyus. In the image we can observe two noblemen collas presenting gifts to its deity, which is dressed in the same outfits as they, including the adornment hanging by the chin.

Lámina 272 de El primer nueva corónica y buen gobierno. Idolos $y$ waqas de los collasuyos. En la imagen podemos observar a dos nobles collas presentando ofrendas a su deidad, la cual se encuentra vestida con los mismos atuendos que ellos, incluido el adorno colgando de la barbilla.

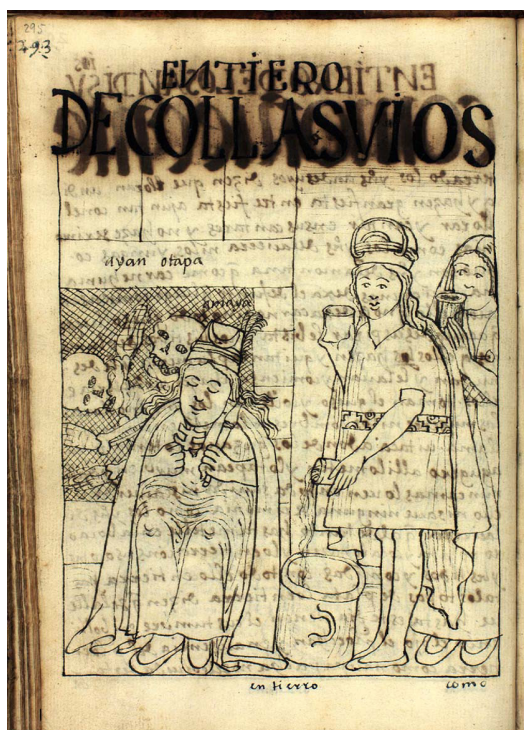

Figure 5c. Drawing 295 of El primer nueva corónica y buen gobierno. Burials of the Qullasuyus. The deceased corresponds to a noblemen colla, who is going to be buried by its clothing and emblems, between them the crescent-shaped diadem and the chin adornment.

Lámina 295 de El primer nueva corónica y buen gobierno. Entierro de collasuyus. El difunto corresponde a un señor colla, que va a ser enterrado con su vestimenta e insignias, entre ellas la diadema y el adorno de barbilla.

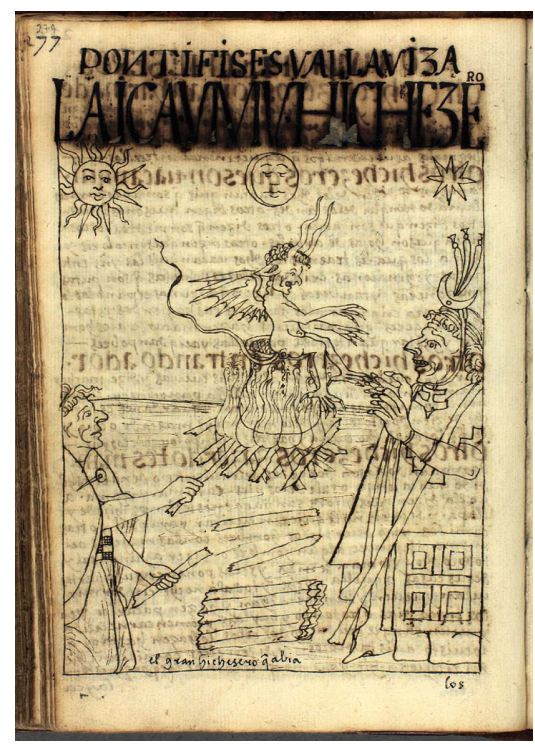

Figure 5b. Drawing 279 of El primer nueva corónica y buen gobierno. High priests, walla wisa, layqha, umu, sorcerer. The one who does the gift in this image is a "sorcerer" colla, whom it is possible to recognize as such due to the crescent-shaped diadem and the chin adornment that it shows.

Lámina 279 de $\mathrm{El}$ primer nueva corónica y buen gobierno. Pontífices, ualla uiza, laica, umu, hechicero. Quien hace la ofrenda en esta imagen es un "hechicero" colla, a quien se puede reconocer como tal debido a la diadema de medialuna y al adorno de barbilla que luce.

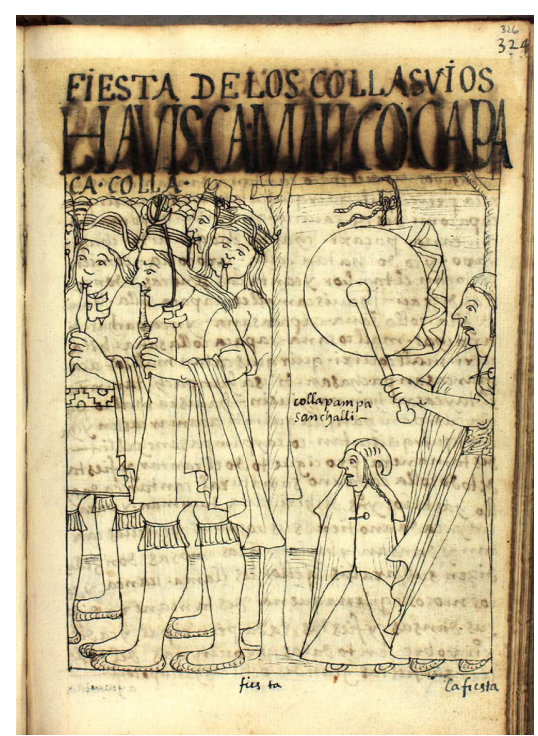

Figure 5d. Drawing 326 of El primer nueva corónica y buen gobierno. Feast of the Qullasuyus. The parade is headed by two colla lords those who show chin adornments.

Lámina 326 de El primer nueva corónica y buen gobierno. Fiesta de los collasuyus. El desfile es encabezado por dos señores collas, quienes lucen adornos de barbilla. 


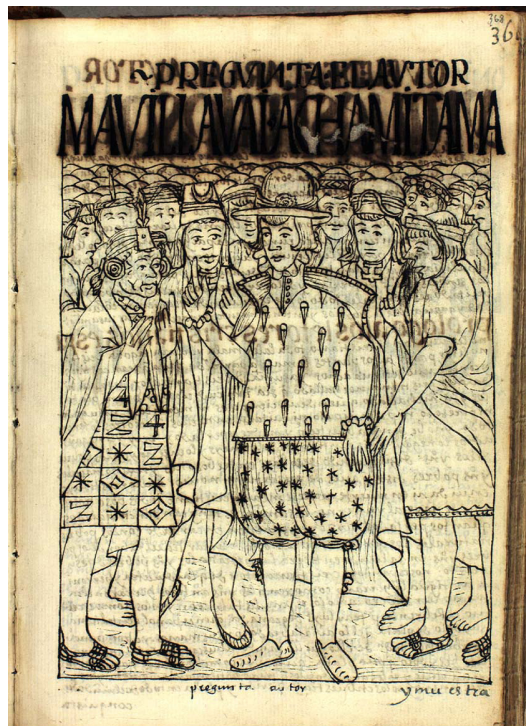

Figure 6a. Drawing 368 of El primer nueva corónica y buen gobierno. Guamán Poma says, "But, tell me," as he inquires about the history of ancient Peru. There flank the author two representatives of the Collasuyo, each one with the adornment hanging by the chin.

Lámina 368 de El primer nueva corónica y buen gobierno. Pregunta el autor, "ma, uillauai ["Pero, díganme"]. Aquí flanquean al autor los dos representantes del Collasuyo, cada uno con el adorno pendiendo de la barbilla.

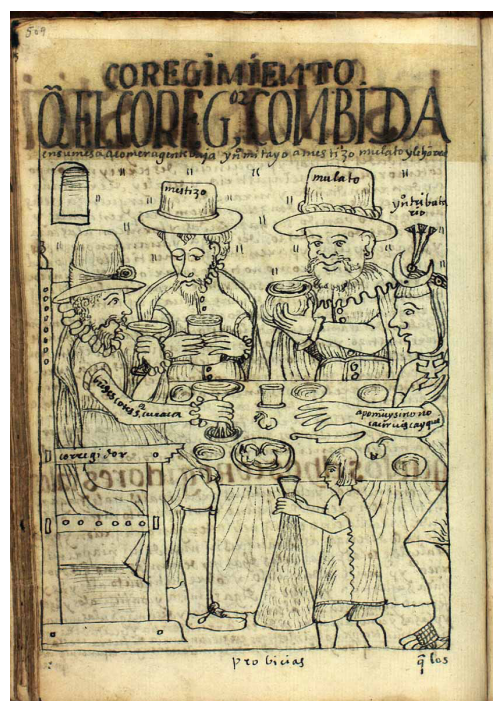

Figure 6c. Drawing 505 of El primer nueva corónica y buen gobierno. The royal administrator and his low-status dinner guests: the mestizo, the mulatto, and the tributary Indian. In this scene figure a tributary Indian with the insignia of his belonging to the nobility: crescent-shaped diadem and chin adornment. Lámina 505 de El primer nueva corónica y buen gobierno. Que el corregidor convida en su mesa a comer a gente baja, indio mitayo, a mestizo, mulato y le honra. En esta escena figura un indio tributario con las insignias de su pertenencia a la nobleza colla: diadema de medialuna y adorno de barbilla.

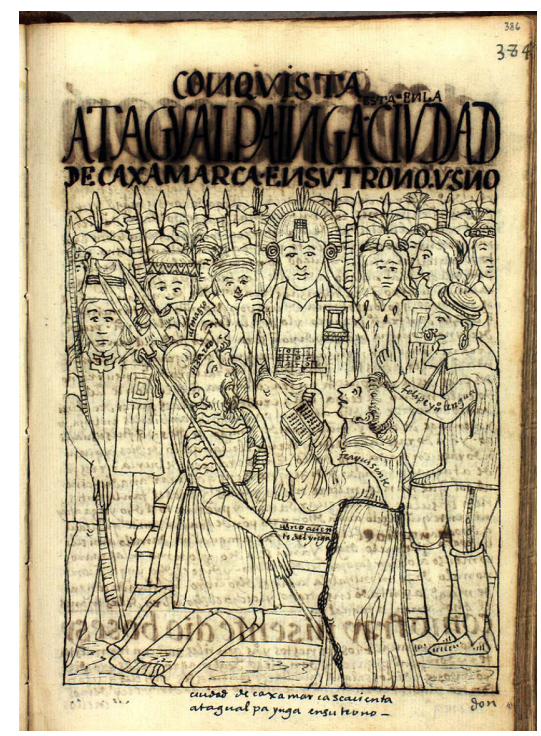

Figure 6b. Drawing 386 of El primer nueva corónica y buen gobierno. Don Diego de Almagro, Don Francisco Pizarro, and Friar Vicente de Valverde kneeling before Atahualpa Inka at Cajamarca. To the right of the Inca, in the foreground, a representative of the Collasuyo appears with the usual attributes, including the chin adornment.

Lámina 386 de $\mathrm{El}$ primer nueva corónica y buen gobierno. Atahualpa Inga está en la ciudad de Cajamarca en su trono, usno. A la derecha del Inca, en primer plano, aparece un representante del Collasuyo con los atributos acostumbrados, incluido el adorno de barbilla.

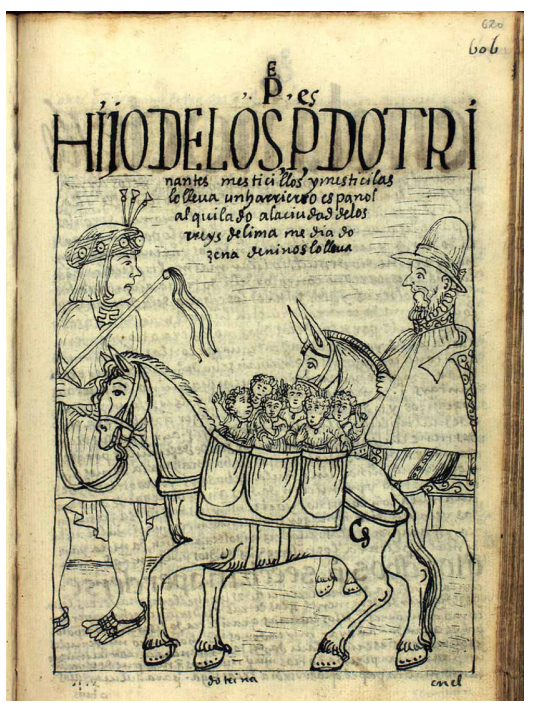

Figure 6d. Drawing 620 of El primer nueva corónica y buen gobierno. The mestizo offspring of parish priests being taken away to Lima. In a scene that develops in the province of the Aymaraes, along with a Spanish muleteer we see a personage with chin adornment leading a horse with alforjas full with six children procreated by priests. Lámina 620 de El primer nueva corónica y buen gobierno. Hijo(s) de los padres doctrinantes. En una escena que se desarrolla en la provincia de los Aymaraes, junto a un arriero español vemos a un personaje con adorno de barbilla conduciendo el cargamento de seis hijos engendrados por curas. 


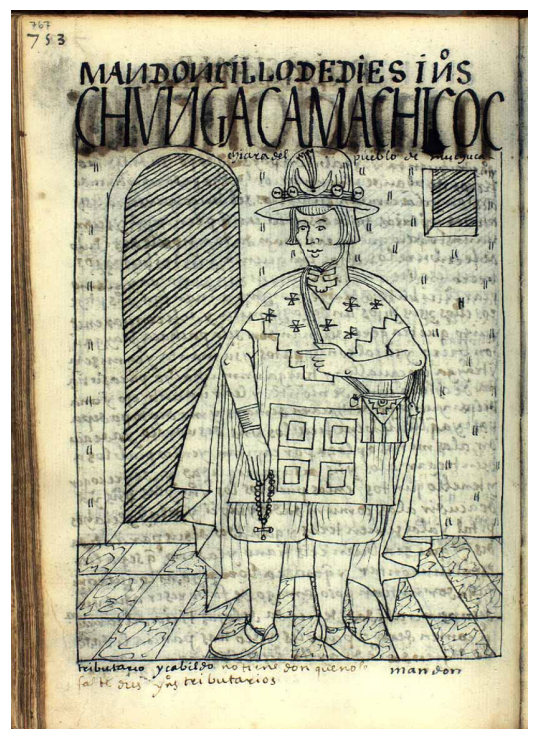

Figure 7a. Drawing 767 of El primer nueva corónica y buen gobierno. Chiara, of the pueblo of Muchuca, chunka kamachikuq, chief of ten native tributaries. Even when the character is portrayed with a dress that mixes native and Hispanic elements, it retains connotative identity attributes: crescent-shaped diadem and chin adornment.

Lámina 767 de El primer nueva corónica y buen gobierno. Mandoncillo de diez indios, chunga camachicoc, Chiara del pueblo de Muchuca. Aun cuando el personaje es retratado con una vestimenta que mezcla elementos nativos e hispanos, conserva los atributos connotativos de su identidad: diadema en forma de medialuna y adorno de barbilla.

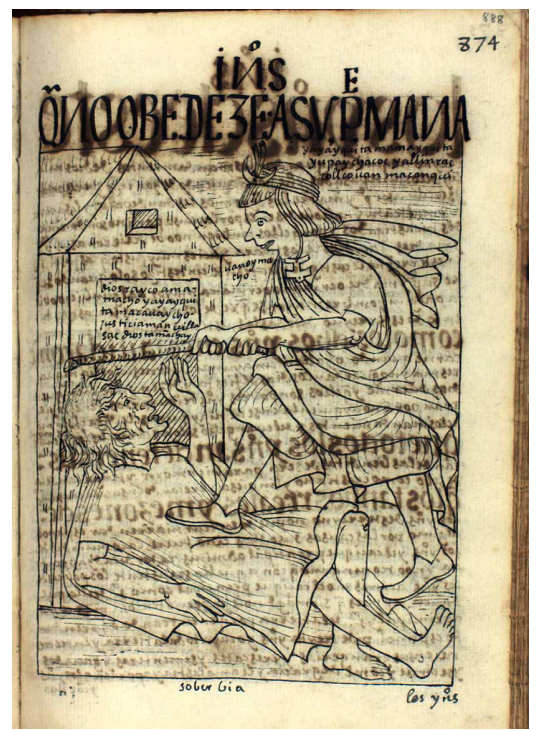

Figure 7c. Drawing 888 of El primer nueva corónica y buen gobierno. A young Andean man violates the Lord's fourth commandment. This young Indian who violent to its father exhibits both the diadem and the chin adornment.

Lámina 888 de El primer nueva corónica y buen gobierno. Indios que no obedecen a sus padres. Este indio joven que violenta a su padre exhibe tanto la diadema como el adorno de barbilla.

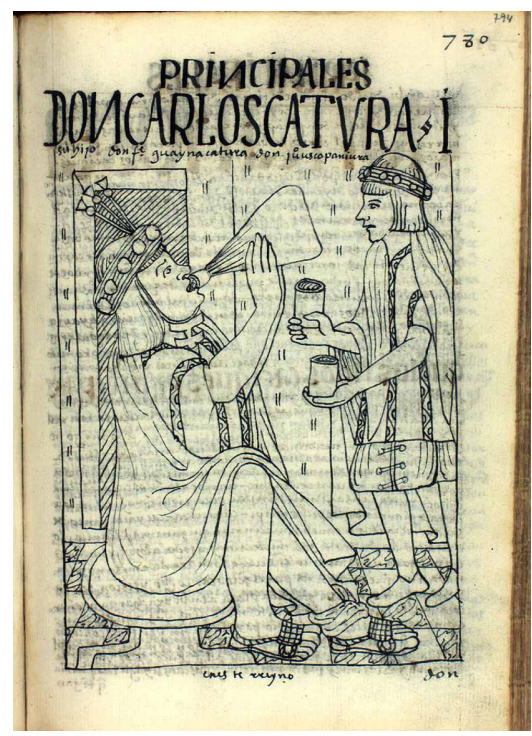

Figure 7b. Drawing 794 of El primer nueva corónica y buen gobierno. Principals. Don Carlos Catura and his son, don Felipe Guayna Catura, don Juan Usco Paniura. This native lord of the Aymaraes also exhibits the chin adornment.

Lámina 794 de El primer nueva corónica y buen gobierno. Principales don Carlos Catura y su hijo, don Felipe Guayna Catura, don Juan Usco Paniura. Este principal de Aymaraes también exhibe el adorno de barbilla.

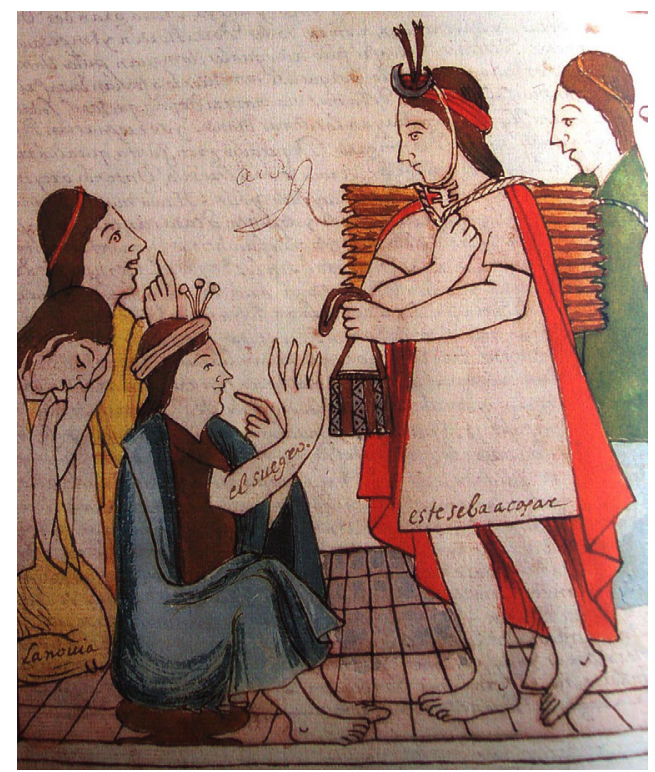

Figure 8. Taken from the work of Fray Martín de Murúa (1946 [1590]). Historia del origen y genealogía real de los reyes Incas del Perú. A young nobleman colla visit to the family of his future wife with identity outfits: the diadem and the chin adornment. Tomado de la obra de fray Martín de Murúa (1946 [1590]). Historia del origen y genealogía real de los reyes Incas del Perú. Un joven noble colla visita a la familia de su futura esposa con los atuendos identitarios: diadema de media luna y adorno de barbilla. 


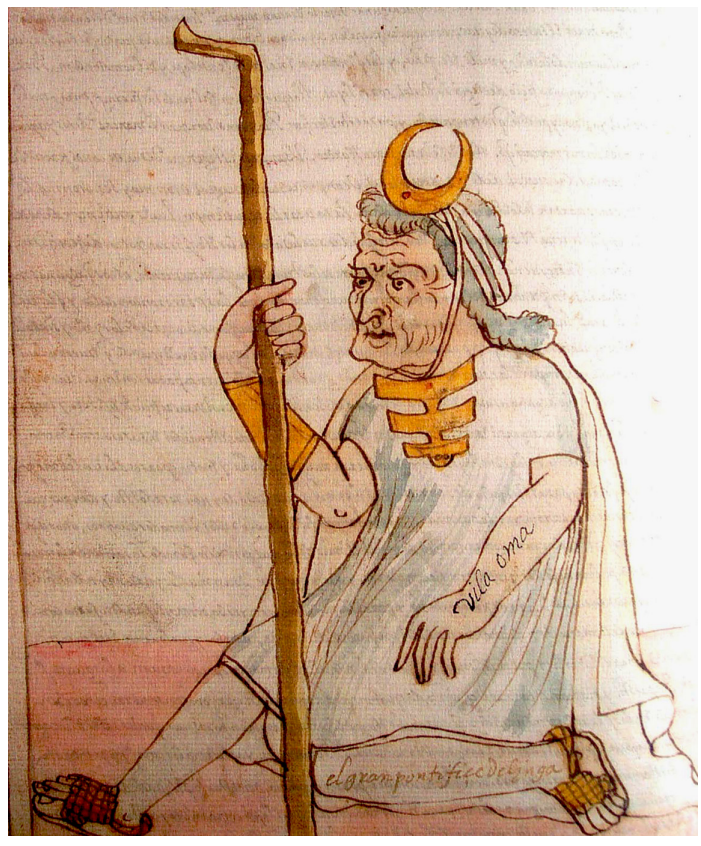

Figure 9. Taken from the work Códice Murúa: Historia y genealogía de los reyes incas del Perú del padre mercedario Fray Martín de Murúa: códice Galvin (2004 [1590]). On the arm of the character can be read: "Vila Oma", and on the leg of the same: "The great pontiff of the Inga"; both inscriptions show the high hierarchy of the individual, which is further reinforced by the use of the crescent-shaped diadem, bracelet or chipana, baton and the chin adornment.

Tomado de la obra Códice Murúa: Historia y genealogía de los reyes incas del Perú del padre mercedario fray Martín de Murúa: códice Galvin (2004 [1590]). En el brazo del personaje se puede leer: "Vila Oma" y en la pierna del mismo: "El gran pontífice del Inga"; ambas inscripciones dan cuenta de la alta jerarquía del individuo, la cual se ve a su vez reforzada mediante el uso de la diadema en forma de media luna, el brazalete o chipana, bastón de mando y el adorno de barbilla.

Near the middle of the securing turn, the cord is much thinner and broken, and we suppose that the crescent-shaped silver adornment was fixed at that point. It was found loose and the shepherds placed it provisionally in the turns of the llautu. The men who discovered the mummy said that they had found this ornament on the child's breast. Due to the position of the head, the adornment did indeed rest on the breast, but Guamán Poma's drawings [...] leave little doubt as to its true position: it was hung from the securing turn of the llautu, beneath the person's chin" (my emphasis; Mostny 1957:35).

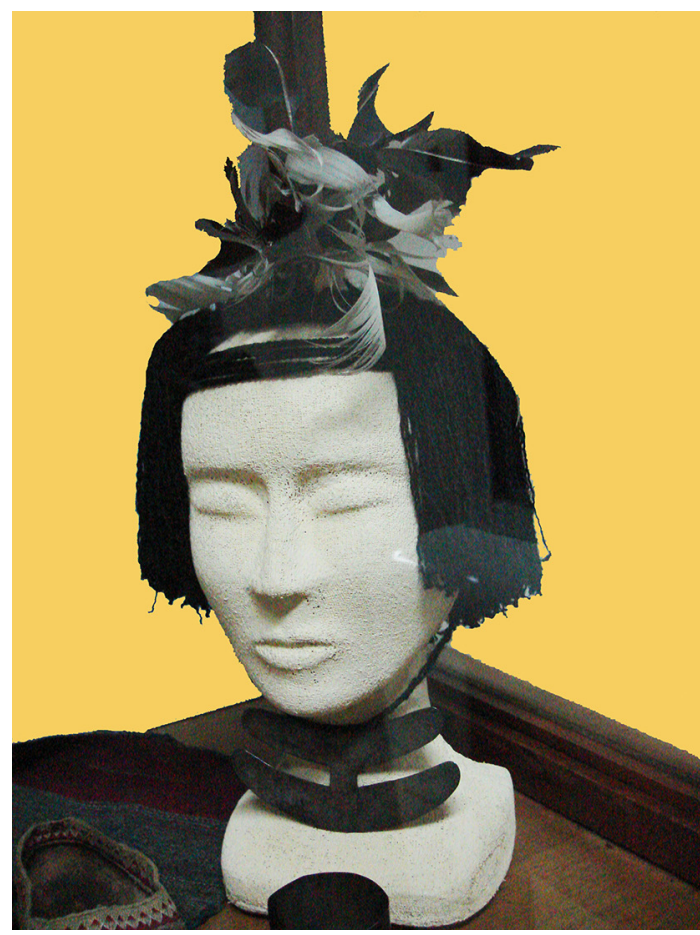

Figure 10. Model figure showing llautu, condor feather plume and chin adornment, elements of the clothing of the Cerro El Plomo child. Museo Nacional de Historia Natural de Santiago, Archaeology section (photograph: author).

Maniquí que exhibe el llautu, el penacho de plumas de cóndor y el adorno de barbilla, elementos del ajuar del Niño del cerro El Plomo. Museo Nacional de Historia Natural de Santiago, sección Arqueología (foto de la autora).

We must stress that only the Collas wear this type of adornment, there are no illustrations with anything similar for the inhabitants of other suyus. Mostny said at the time that "at all events it is a fact that all the people identified as representatives of the Collasuyo in Guamán Poma's chronicle wear moccasins and the same silver adornment" (Mostny 1957:56). We can indeed confirm this concurrent appearance of the use of moccasins (hisccu in Aymara) and the chin adornment (Figures 4c, 5c, $5 \mathrm{~d}, 6 \mathrm{a}$ and 21). Möntell is another researcher who noticed at an early date the formal similarity between the adornment worn by the altiplano lords and the specimen published by Bandelier (Möntell 1929).

\section{Investigating the Antiquity of the chin Adornment}

Tiawanaku iconography presents little variety in the insignias associated with the Staff-Bearing 
Deity or his accompanying icons, whether falconid or feline; they form a somewhat sparse, cryptic visual language which abounds in rather metaphorical representations. Nevertheless, in some censers in feline shape, the neck of the animal is seen to bear an element which, by its form and location, might represent the use of the chin adornment subject of this work (Figures 1113). There are also queros -from Tiahuanaco and Pariti Island-which represent a falconid or feline with a similar adornment ${ }^{6}$ (Figures 14 and 15), as well as the Staff-Bearing Deity himself, both in his abbreviated form as the rayed head (Figure 16a) and as a whole body (Figures 16b and 16c). In these cases, the ornament presents a more geometrical, rectilinear form, being reduced to a double letter " $\mathrm{H}$ " or an " $\mathrm{H}$ " on its side.

We also find a fairly close correlation between this adornment and the Staff-Bearing Deity of Huari iconography, as we see in images in a ceramic piece

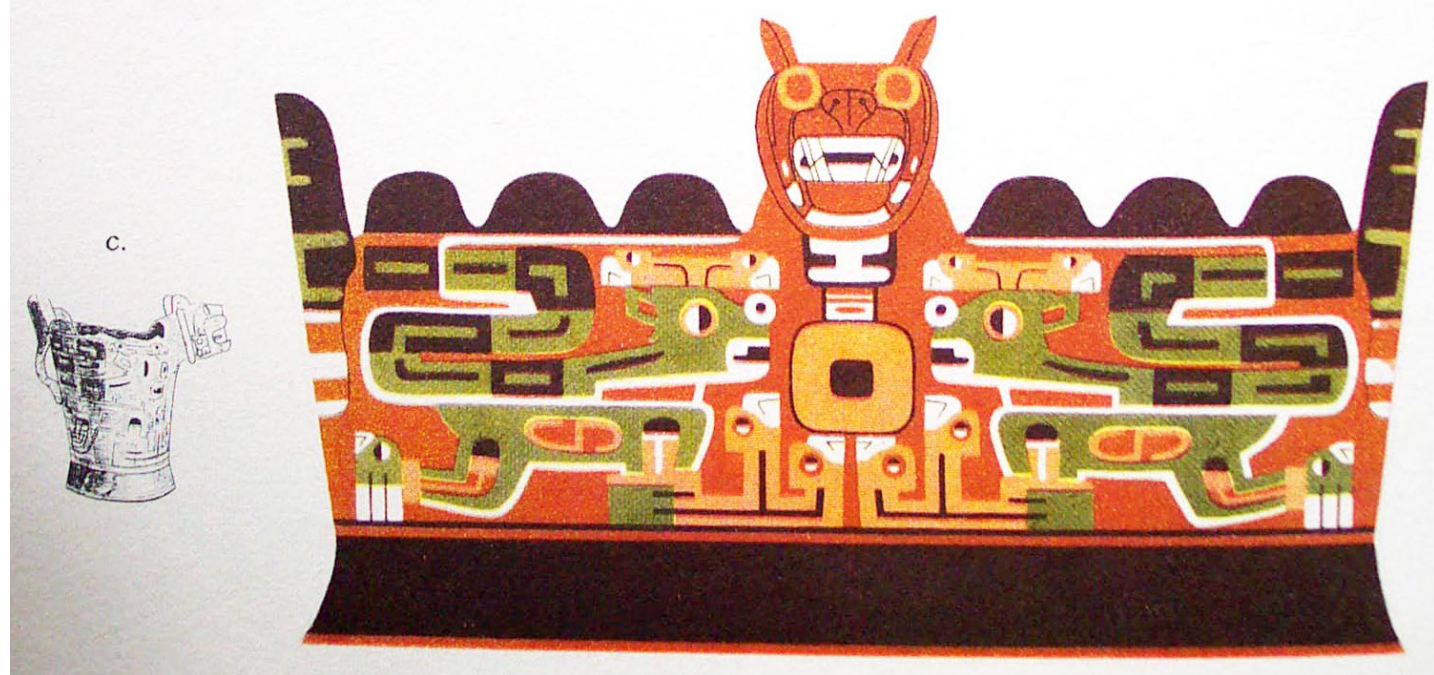

Figure 11. Censer with modelled feline head (taken from Posnansky 1945: Plate XIc). Incensario con cabeza modelada de felino (tomado de Posnansky 1945: Plancha XIc).

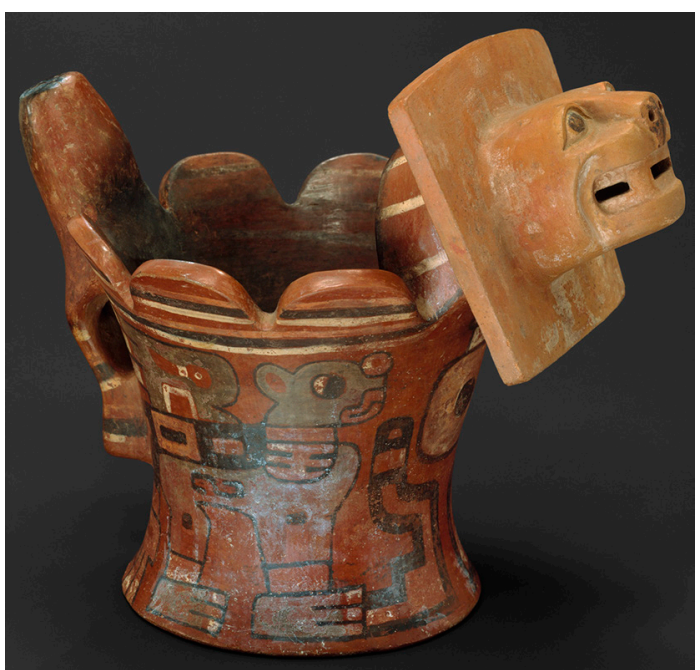

Figure 12. Censer with modelled feline head (taken from the web site of the Metropolitan Museum of Arts, New York, Inventary $\mathrm{N}^{\mathrm{o}}$ 1978.412.100).

Incensario con cabeza modelada de felino (tomado del sitio web del Metropolitan Museum of Arts, New York, $N^{o}$ inventario 1978.412.100).

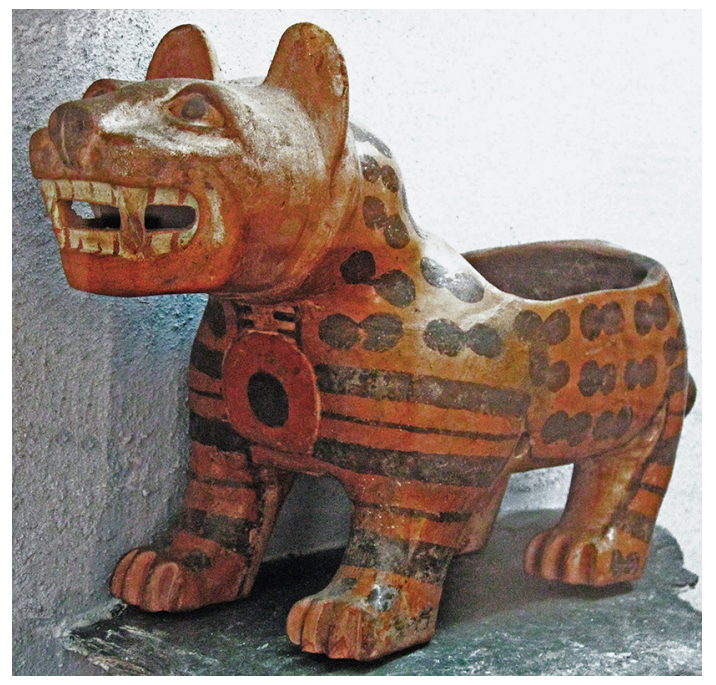

Figure 13. Censer modelled in feline form; Museo de Tiahuanaco, La Paz (photograph: author).

Incensario en forma de felino; Museo de Tiahuanaco, La Paz (foto de la autora). 


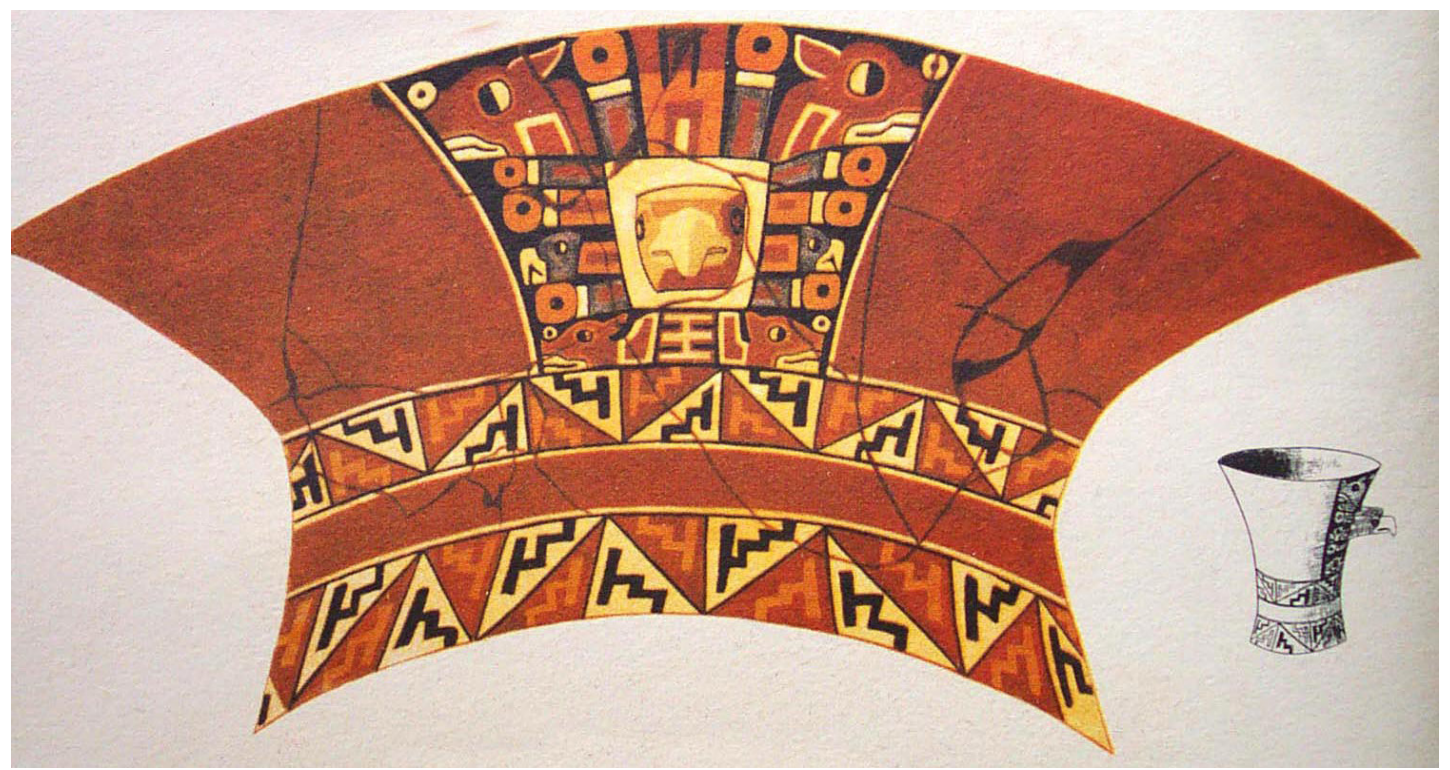

Figure 14. Quero with falconid head in haut-relief (taken from Posnansky 1945: Plate XIb). Quero con cabeza de falcónida en sobrerrelieve (tomado de Posnansky 1945: Plancha XIb).

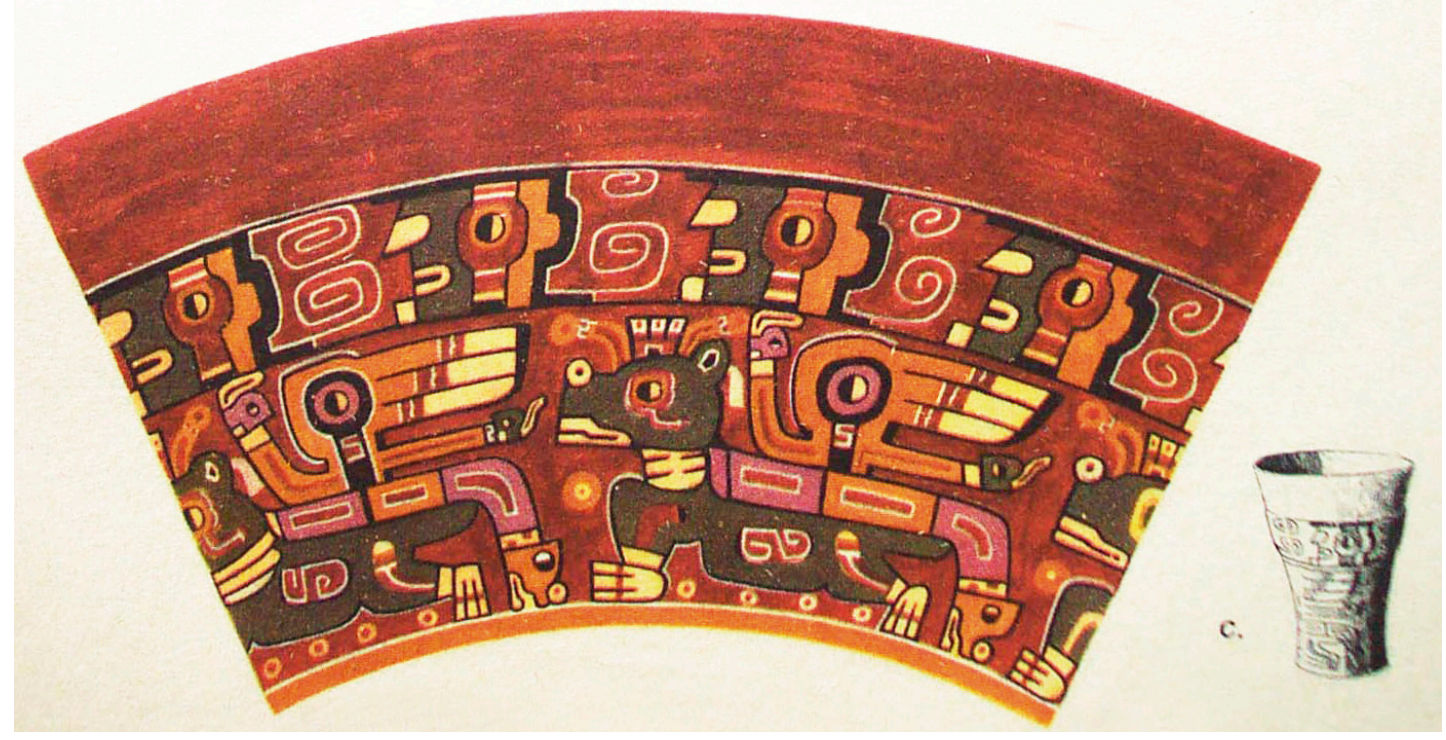

Figure 15. Quero with painted felines (taken from Posnansky 1945: Plate XIVc).

Quero con felinos pintados (tomado de Posnansky 1945: Plancha XIVc).

offered in Conchopata (Figure 16d), and in a textile called "Fire textile" (Figure 16e). In the two latter cases, the representation of the chin adornment differs slightly from that observed in Tiawanaku iconography, in that the letter " $\mathrm{H}$ " is accompanied by a line framing its external outline; in one of the cases the letter presents a step, but even so, from the general shape and location under the chin we may suppose that this could be the same adornment. The style of the representation presents certain variability; for example, in Tiawanaku iconography we may see it with two or three appendages, in both a curving version and another straighter one which looks like a letter " $H$ "; in the Huari images we observe adornments with two straight appendages with double outline (Figures 16d and 16e); in Guamán 


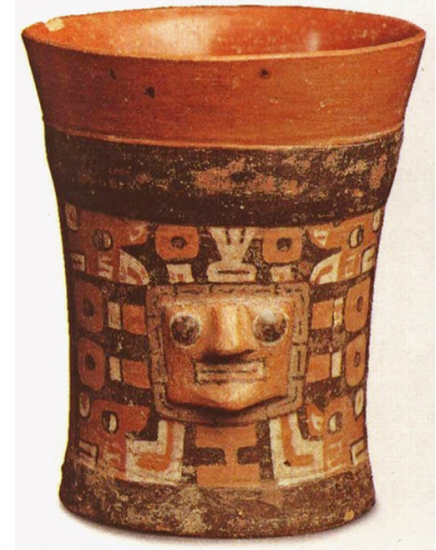

Figure 16a. Quero with Staff-bearing Deity (Albarracín-Jordán 2007: 6.17).

Quero con la Deidad de los Cetros (Albarracín-Jordán 2007: 6.17).

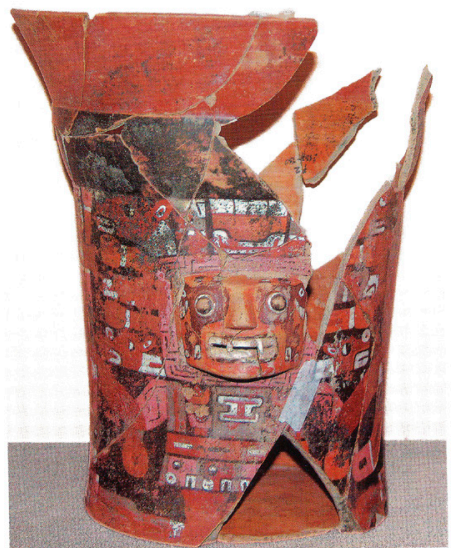

Figure 16c. Quero with Staff-bearing Deity found in Pariti (taken from Korpisaari and Pärssinen 2005: Fig. 46).

Quero con la Deidad de los Cetros encontrado en Pariti (tomado de Korpisaari y Pärssinen 2005:Fig. 46).

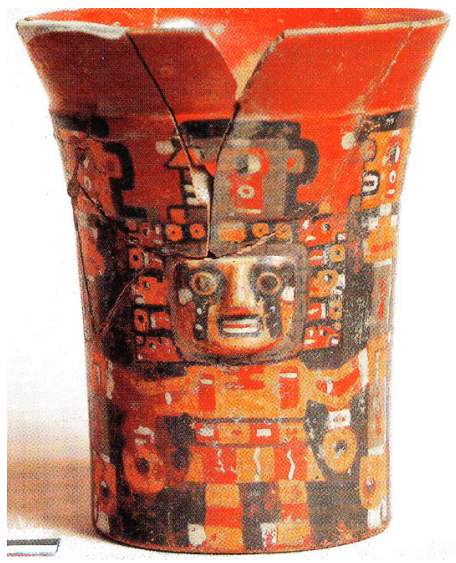

Figura 16b. Quero with Staff-bearing Deity found in Pariti (taken from Korpisaari and Pärssinen 2005:Fig. 43).

Quero con la Deidad de los Cetros encontrado en Pariti (tomado de Korpisaari y Pärssinen 2005:Fig. 43).

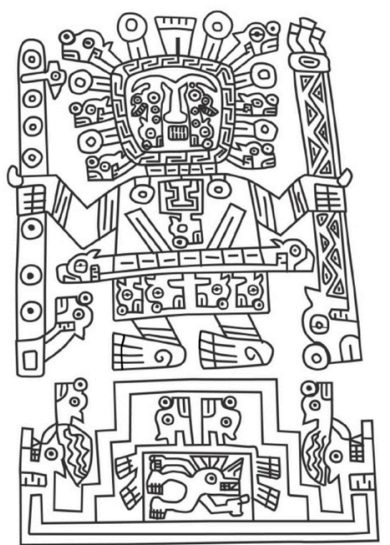

Figure 16d. Staff-bearing Deity painted on a vessel from Conchopata (taken from Isbell and Knobloch 2008: 12.5).

Deidad de los Cetros pintada en vasija de Conchopata (tomado de Isbell y Knobloch 2008:12.5).

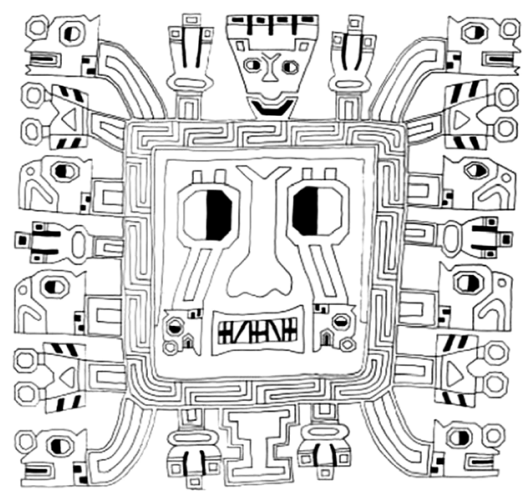

Figura 16e. Rayed head of the Staff-bearing Deity, motif on a textile garment (Conklin 2004 cited in Isbell and Knobloch 2008: 12.9c).

Cabeza radiada de la Deidad de los Cetros, motivo de una prenda textil (Conklin 2004 citado en Isbell y Knobloch 2008:12.9c). 
Poma's pictures it appears with two appendages in a curved version, while Murúa shows it on one occasion with three appendages in a curved version (Figure 9). Finally, the archaeological specimens present only two appendices in a curved version which connects them closely with the insignia of a figure in a coat of arms of the colonial period which we will analyse later.

As we see, in each of these representations the adornment is placed below the chin, and may present either two or three crescent-shaped elements. The pictures suggest that the chin adornment would have been found associated with the central deity of the Tiawanaku and Huari iconography, in addition to the feline manifestation of the Sacrificer in Tiawanaku art (Figures 17a and 17b), in which the head of the feline bears a severed human limb in its headdress, in this case a human leg7. Based on parallels with the iconography on hallucinogenic paraphernalia from the altiplano found in tombs at San Pedro de Atacama dating from the Middle period, specifically containing tubes of bone with pyro-engraved figures, we know that among the attributes of the felinised Sacrificer were taruca antlers (Hippocamelus antisensis), as well as the representation of severed human limbs and sacrificial axes, as we see in Figure 17c. This association is not casual: the principal personages of the altiplano religious system were closely linked to human sacrifice carried out as an offering to the deity(ies) which controlled the weather (Blom et al. 2003; Manzanilla 1990; Reinhard 1991; Verano 2013); in broad terms, the huacas received permanent sacrifices from human society, in return for which they provided rain, good harvests and well-being.

To return to the analysis of Guamán Poma's pictures, we have already noted the fact that the individuals shown wearing the chin adornment are exclusively Collas of high rank or local native authorities (curaca, principal, captain), or experts in the rites and ceremonies ("sorcerers") ${ }^{8}$; this makes it clear that this metal adornment was not only the insignia of political power but also of religious power. This idea is reinforced by image 272, in which two altiplano lords wearing tunics, one of them carrying truncated cone cap, the other hemispherical cap ${ }^{9}$ and Colla insignias present offerings to a huaca located at the top of a mountain; the exceptional feature is that the deity wears the same clothing and insignia in the form of a chin adornment as the individuals making the offering (Figure 5a). There is no other situation in Guamán Poma's whole work which is so

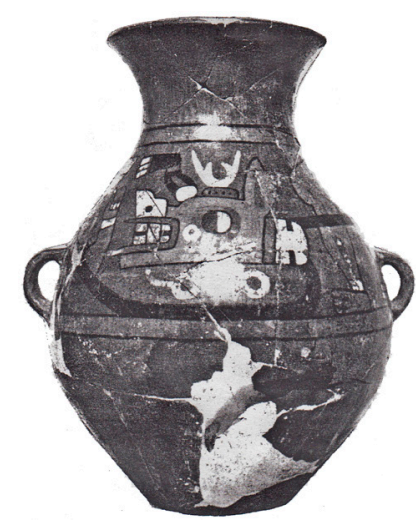

Figure 17a. Vessel (taken from Ponce Sanginés 1981:Fig. 88). Vasija (tomada de Ponce Sanginés 1981:Fig. 88).

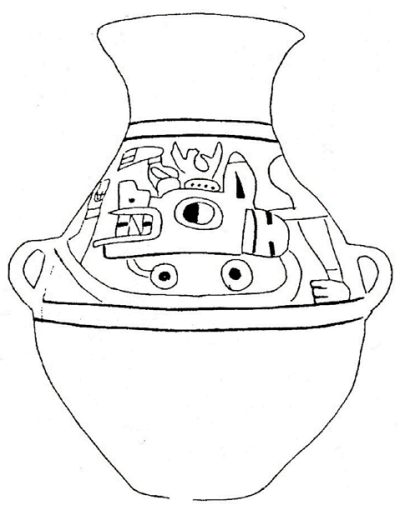

Figure 17b. Drawing of the iconography of the same vessel by A. Cook (1994: 50a).

Dibujo de la iconografía de la vasija anterior realizado por A. Cook (1994: 50a).

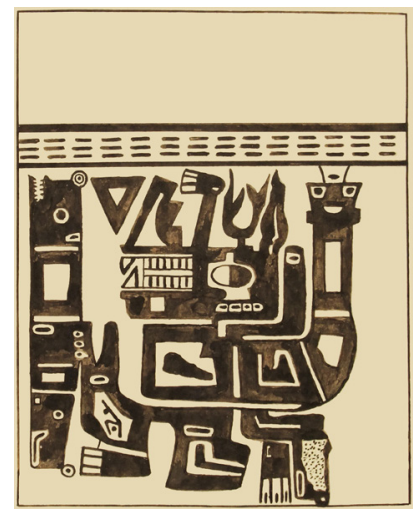

Figure 17c. Drawing by G. Le Paige of the decoration on a pyro-engraved bone from tomb 2153, Quitor 5 cemetery (taken from Le Paige 1965: Pl. 52); belongs to the collection of the Instituto de Investigaciones Arqueológicas y Museo R.P. Gustavo Le Paige S.J., San Pedro de Atacama, Universidad Católica del Norte. Dibujo de G. Le Paige sobre la decoración de un hueso pirograbado procedente de la tumba 2153 del cementerio Quitor 5 (tomado de Le Paige 1965: Lám. 52). Pertenece a la colección del Instituto de Investigaciones Arqueológicas y Museo R.P. Gustavo Le Paige S.J., San Pedro de Atacama, Universidad Católica del Norte. 
explicit as this with respect to altiplano adornment, indicating the special nature of the insignia.

Here we should also note that when the chronicler draws the different ethnic groups according to their division into suyus, as they make mochas or offerings to their huacas, the coincidence between the headdress and tunic worn by the huaca and the curaca only appears clearly in two cases: those of the inhabitants of Collasuyu and of Chinchaysuyu (Figure 18), and only in the case of the Collas is a personal adornment illustrated. In the case of the other two suyus, the huacas appear without vestments or personal adornments, as we see in Figure 19 which represents an inhabitant of Contisuyu adoring his huaca; the latter also is not wearing a vestment or headdress and is at the top of Coropuna Volcano. I believe that the difference observed in this respect may be due to the particularity of the Colla adornment, hung below the chin, and also associated with the crescent-shaped diadem on the forehead. As we have seen, it is very likely that the

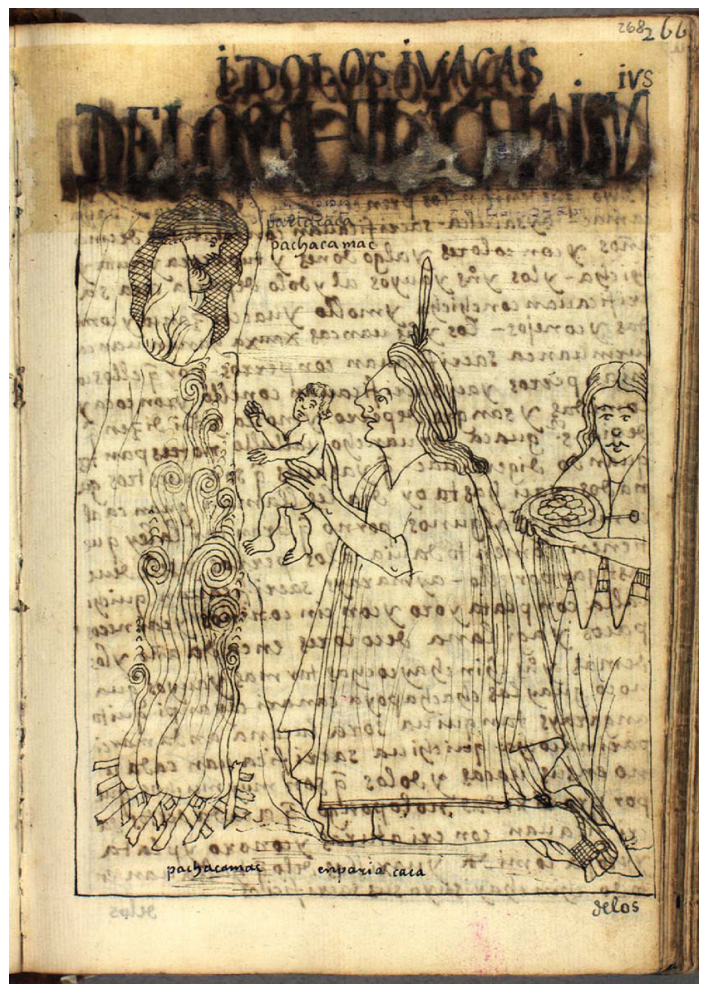

Figure 18. Inhabitants of Chinchaysuyu making an offering to their huaca in Pachacamac. Plate 268 of El primer nueva corónica y buen gobierno.

Habitantes del Chinchaysuyu ofrendando a su huaca en Pachacamac. Lámina 268 de El primer nueva corónica y buen gobierno. chin adornment was a very ancient emblem among the lords of the altiplano, serving as a concrete visual symbol of political and religious power, and that it was illustrated in special detail precisely because of its long-standing use and deeply-rooted tradition.

In the universe of the insignias ascribed to the high-ranking persons in the Corónica, it is clear that the chin adornment -like the crescent with which it is associated-is an important metal emblem whose role appears similar in prestige and importance to that of the Inca insignias, the canipu and the tincurpa (Horta 2008) (Figure 20). From this we may infer that the chin adornment distinguished the Collas, investing them with a special status and perhaps indicating a hierarchy comparable to that of the Incas. Although the horseshoe-shaped insignia also existed, worn on the forehead by Chinchaysuyo dignitaries, it appears much less frequently in Guamán Poma's work; nevertheless, both are included in the illustration of the Royal Council presided over by the ruling Inca (Figure 21).

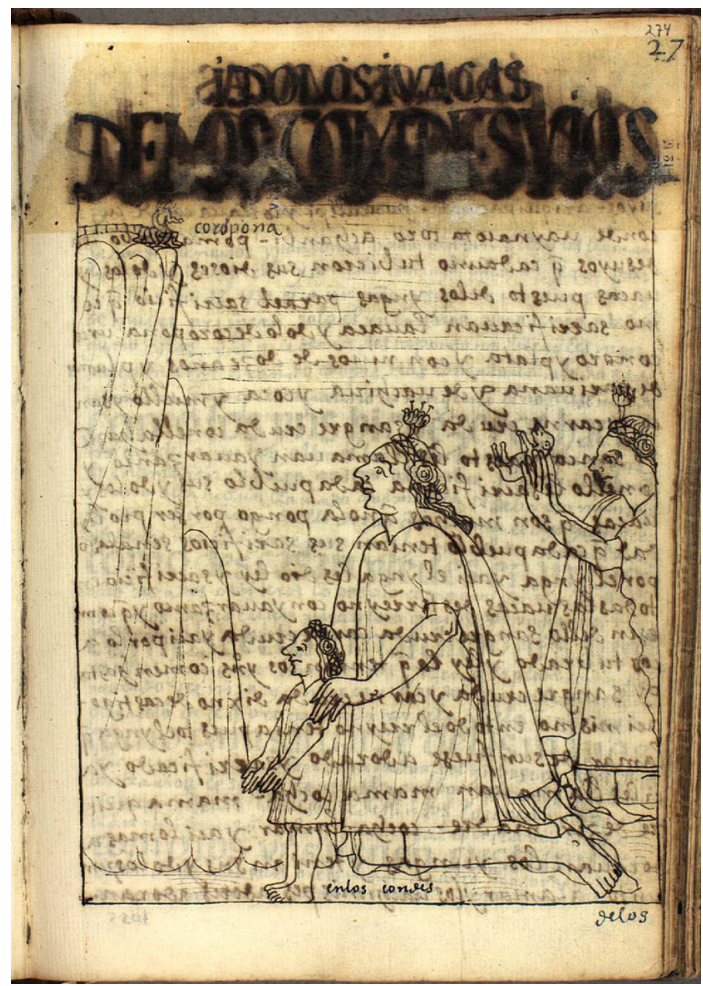

Figure 19. Inhabitants of Condesuyu making an offering to their huaca. Plate 274 of El primer nueva corónica y buen gobierno (1613-1615), Felipe Guamán Poma de Ayala.

Habitantes del Condesuyu ofrendando a su huaca. Lámina 274 de El primer nueva corónica y buen gobierno (1613-1615), Felipe Guamán Poma de Ayala. 


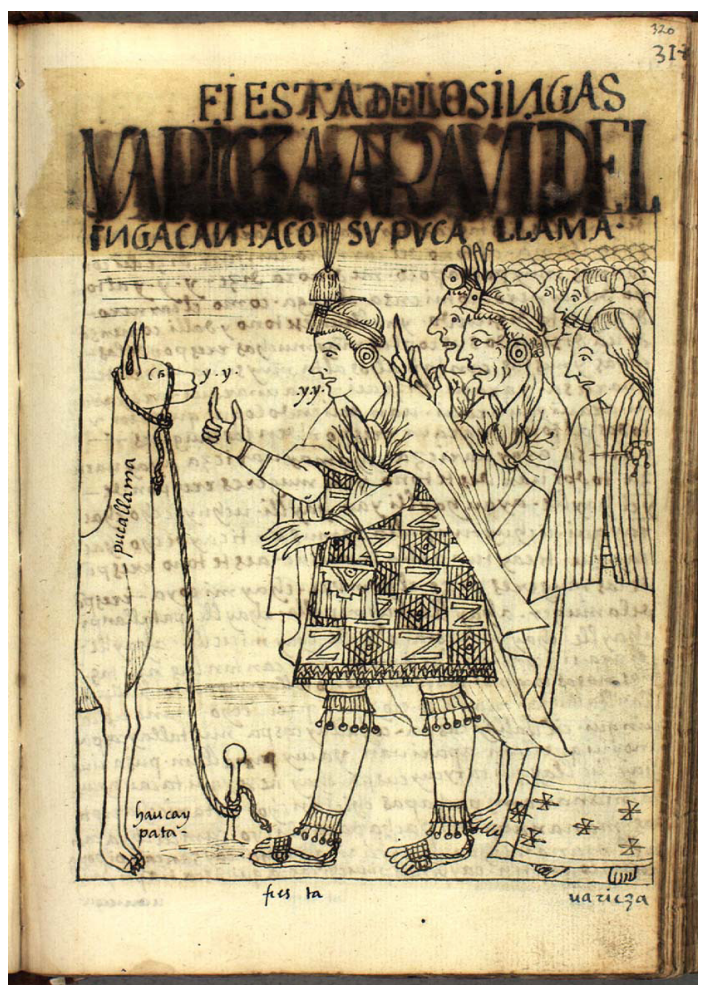

Figure 20. The Inca with mascapaycha on his forhead and two nobles with their insignia, one with a canipu and the other with a tincurpa. Plate 320 of El primer nueva corónica y buen gobierno (1613-1615), Felipe Guamán Poma de Ayala.

El Inca con mascapaycha en la frente y dos nobles con las respectivas insignias canipu $y$ tincurpa. Lámina 320 de El primer nueva corónica y buen gobierno (1613-1615), Felipe Guamán Poma de Ayala.

\section{Epilogue to the Chin Adornment}

Platt has recently published a very interesting work on the Proof presented to the King of Spain in 1635 by don Fernando Ayra de Ariutu, a mallku of the Inca province of Qaraqara, in order to obtain the grant of an encomienda and a coat-of-arms as suited his dignity. The proof included a "template" or sketch of the elements which don Fernando asked to have included in his coat-of-arms (Platt 2015). The author says: “... analysis of a coat-of-arms can offer us, I believe, a fresh perspective on the mining and religious history of South Andean societies under Inca and Spanish rule and on the workings of collective memory under the pressures of colonialism" (Platt 2015:239). Don Fernando's choice of the elements which he wished to include is based on an ancient stratum composed of pre-Hispanic religious emblems,

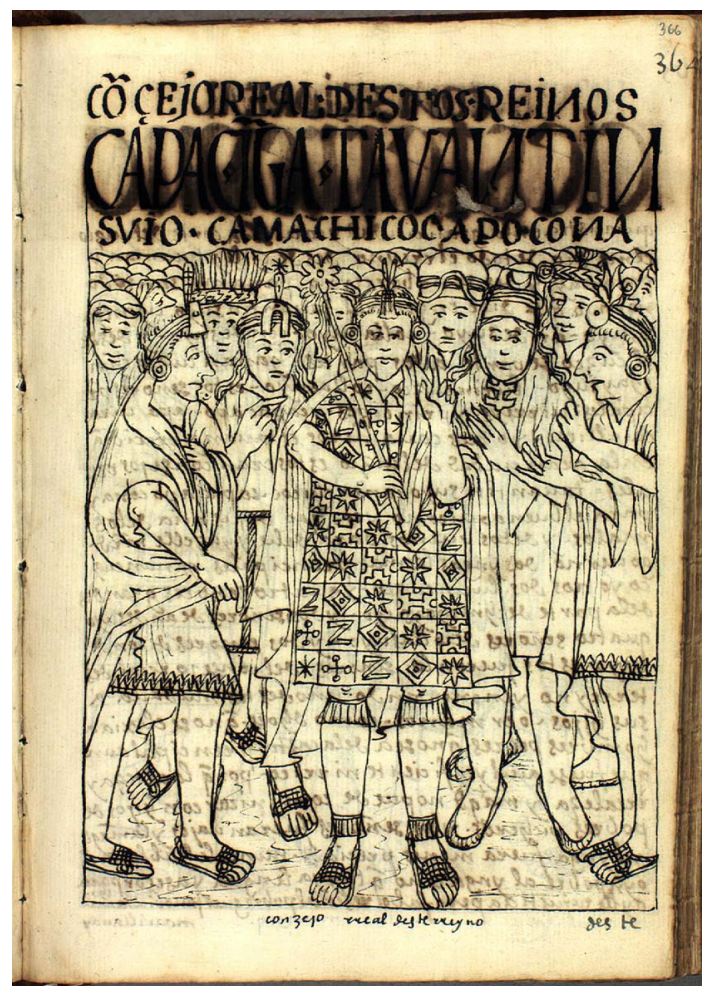

Figure 21. Royal Council of this Kingdom with the Inca in the foreground flanked by two noblemen from Cusco and accompanied by the representatives of the four suyus. Note the representative of Collasuyu with chin adornment and crescent on his forehead. Plate 366 of El primer nueva corónica y buen gobierno. Consejo Real de este Reyno con el Inca en primer plano, flanqueado por dos nobles cusqueños y acompañado por los representantes de los cuatro suyus. Nótese el representante del Collasuyu con adorno de barbilla y medialuna en la frente. Lámina 366 de El primer nueva corónica y buen gobierno.

such as the feline, the condor, the morning star, etc. According to Platt, "Don Fernando's request was, therefore, part of a view of the colonial order that made its legitimacy dependent on pre-Hispanic precedent" (Platt 2015:249).

Thus Fernando Ayra de Ariutu appeals to ancient emblems of political and religious power to impose rights which have been infringed by the Spanish, as Platt notes in his conclusions: "In the case of the Qaraqara, we can observe a pre-hispanic dynasty refounding itself and appealing to regional collective memories in order to prolong its jurisdiction and privileges by re-membering pre-Hispanic events and knowledge within a colonial frame" (Platt 2015:262). Among the symbols through which don Fernando represents himself in the coat-of-arms is the emblem worn hanging from the neck, which Platt remarks is linked to the Collasuyu and the drawings 
of Guamán Poma (Figure 22) ${ }^{10}$. Discounting minor formal differences such as the size of the insignia, the central bar which in this case is divided and the long distance between the upper and lower appendage, we see that when this Aymara-speaking lord needed to appeal to the ethnic memory of his confederation to demonstrate his ancestral rights, he had recourse to the old chin adornment of the times of the Tiawanaku.

By way of conclusion, in this article we have proposed that evidence from Tiawanaku iconography demonstrated use of the chin adornment over a long period, since it was apparently an emblem of the Staff-Bearing Deity, as well as appearing in feline and falconid forms and on huacas of the Bolivian altiplano during the Middle period or Tiawanaku Horizon. During the Late period this adornment would have denoted belonging to the Collasuyu, witnessed by the attire of the Cerro El Plomo child; it would also have functioned as the equivalent of the insignias used by Inca nobles (canipu and tincurpa), denoting the nobility of their political and religious status (high-ranking Collas and specialists in ritual). During early colonial times, this adornment would have constituted an emblem of ethnic identification, as well as denoting political status (worn by highranking Collas) and religious power (worn by both the huaca and specialists in ritual). From the testimony of Fernando Ayra de Ariutu 's coatof-arms and the drawings of Guamán Poma and Murúa, we may conclude that in the general array of colonial signs and symbols, the chin adornment served particularly for ethnic identification in Collao, and continued to do so into the early 17 th century. If my observations are correct, we have here an unprecedented case of cultural continuity for this emblem of political-religious power in the altiplano of the South Andes, the symbolic significance of which lasted for a thousand years.

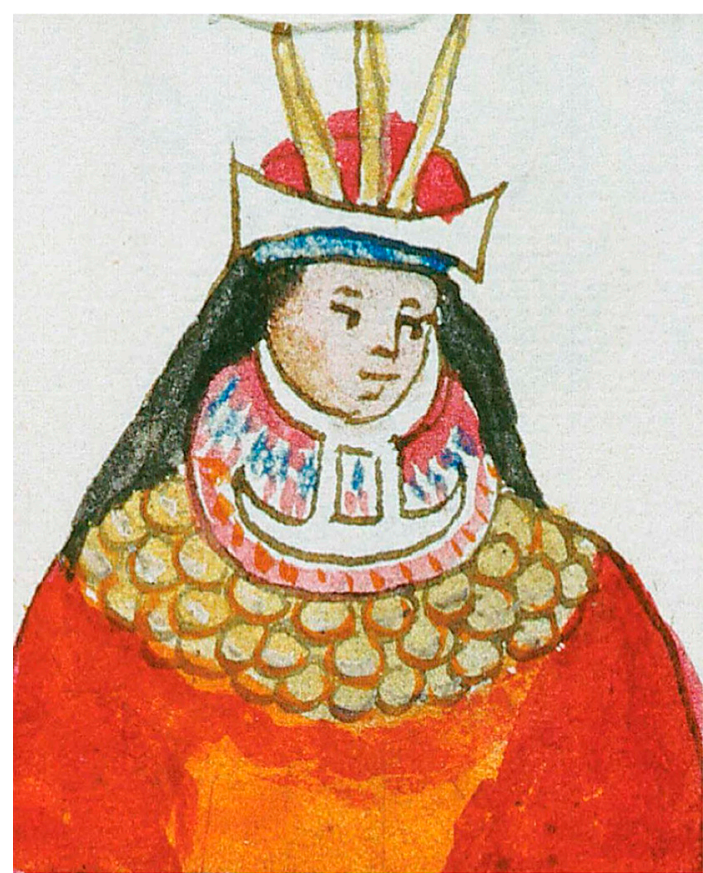

Figure 22. Detail of the coat of arms applied by don Fernando Ayra de Ariutu (taken from Platt 2015: Fig. 12.12, Archivo General de Indias, MP-Escudos 75).

Detalle del blasón solicitado por don Fernando Ayra de Ariutu (tomado de Platt 2015:Fig. 12.12, Archivo General de Indias, MP-Escudos 75).

Acknowledgements: I express my thanks to the evaluators, whose dedicated work helped improve aspects of the original manuscript. At the same time, I appreciate the invitation made me the organizers Maria de los Angeles Muñoz and Isabel Combès to participate in the International Congress of Archaeology and Etnohistoria in the Andes and the lowlands, meeting that was unforgettable for all who attended.

\section{References Cited}

Albarracín-Jordán, J. 2007. La Formación del Estado Prehispánico en los Andes. Origen y Desarrollo de la Sociedad Segmentaria Indígena. Fundación Bartolomé de las Casas, La Paz.

Arriaga, P.J. de 1964 [1621]. Extirpación de la idolatría del Pirú. In Crónicas Peruanas de Interés Indígena, ed. F. Esteve Barba 191-277. Biblioteca de Autores Españoles 209, Madrid.

Bandelier, A.F. 1910. The Islands of Titicaca and Koati. The Hispanic Society of America, New York.

Bertonio, L. 1956 [1612]. Vocabulario de la Lengua Aymara. La Paz.
Blom, D., J. Janusek and J. Buikstra 2003. A Re-evaluation of human remains from Tiwanaku. In Archaeology and Paleoecology in the Tiwanaku Heartland. Vol. II, Rural and Urban Archaeology, edited by A.L. Kolata, pp. 435-448. Smithsonian Institution Press, Washington, DC.

Castillo Narrea, L. 2008. Conservación y Restauración de Algunos Objetos Arqueológicos: Arte, Técnica y Metalurgia. Procedentes de Tres Sociedades Contemporáneas: Sicán, Chimú y Chiribaya. Tesis de Diplomado en Restauración del Patrimonio Cultural, Facultad de Artes, Escuela de Posgrado, Universidad de Chile, Santiago. Manuscrito en poder del autor. 
Catálogo de exhibición 2001. Varios autores. Tras la Huella del Inca en Chile, catálogo de exhibición del Museo Chileno de Arte Precolombino, Santiago.

Cobo, B. 1964 [1653]. Historia del Nuevo Mundo II. In Obras del P. Bernabé Cobo de la Compañía de Jesús (estudio preliminar y edición del P. Francisco Mateos). Biblioteca de Autores Españoles 92, Madrid.

Cook, A. 1994. Wari y Tiwanaku: entre el Estilo y la Imagen. Pontificia Universidad Católica del Perú, Fondo Editorial, Lima.

Couture, N. and K. Sampeck 2003. Putuni a History of Palace Architecture at Tiwanaku. In Tiwanaku and its Hinterland: Archeology and Paleoecology of an Andean Civilitation: 2 Urban and Rural Archaeology, edited by A.L. Kolata, pp. 226-263. Smithsonian Institution Press, Washington, D.C.

Duviols, P. 1976. La Capacocha. Mecanismo y función del sacrificio humano, su proyección geométrica, su papel en la política integracionista y en la economía redistributiva del Tawantinsuyu. Allpanchis 9, Ritos y Rituales Andinos, Vol. IX, Cusco.

Guamán Poma de Ayala, F. 1980 [1615]. El Primer Nueva Corónica y Buen Gobierno. Edición crítica de John V. Murra y Rolena Adorno. Traducción de L. Urioste. 3 vols. Siglo XXI Editores, México.

Horta T., H. 2008. Insignias para la frente de los nobles incas: una aproximación etnohistórica- arqueológica al principio de la dualidad. In Lenguajes Visuales de los Incas. Actas del Simposio ARQ 3 del $52^{\circ}$ Congreso Internacional de Americanistas, Sevilla 2006. Serie British Archaeological Review (B.A.R.) S 1848, edited by P. González Carvajal y T.L. Bray, pp. 71-89, Oxford.

Horta T., H. 2010. El Señorío Arica y los Reinos Altiplánicos. Complementariedad Ecológica y Multietnicidad en el CentroSur Andino (1000-1540 D.C.). Ph.D. Thesis from Programa de Doctorado en Historia con Mención Etnohistoria del Departamento de Ciencias Históricas, Facultad de Filosofía y Humanidades, Universidad de Chile, Santiago.

Horta T., H. 2011a. El gorro troncocónico o chucu y la presencia de población altiplánica en el norte de Chile durante el período Tardío (ca. 1470-1536 d.C.). Chungara Revista de Antropología Chilena 43:551-580.

Horta T., H. 2011b. Nuevos indicadores arqueológicos de la presencia altiplánica en Valles Occidentales durante el período Tardío. Actas de la XXIII Reunión Anual de Etnología, pp. 17-40, Museo Nacional de Etnografía y Folklore (MUSEF), La Paz.

Horta T., H. 2015. El Señorío Arica y los Reinos Altiplánicos (1000-1540 d. C.). Complementariedad Ecológica y Multietnicidad durante los Siglos Pre-Conquista en el Norte de Chile. QILLQA Ediciones IAA, Instituto de Arqueología y Antropología-San Pedro de Atacama, Universidad Católica del Norte, Ocho Libros Editores Ltda., Santiago.

Isbell, W.H. and P. Knobloch 2008. Missing links, imaginary links: Staff god imagery in the South Andean Past. In Andean Archaeology III, North and South, edited by W.H. Isbell and H. Silverman, pp. 307-351. Springer Science\&Business Media, New York.

Korpisaari, A. and M. Pärssinen (eds.) 2005. Pariti: Isla, Misterio y Poder. El Tesoro Cerámico de la Cultura Tiwanaku. Producciones CIMA, La Paz.
Korpisaari, A. and M. Pärssinen 2011. Pariti. The Ceremonial Tiwanaku Pottery of an Island in Lake Titicaca. Academia Scientiarum Fennica, Helsinki.

Larrea, J. 1960. Corona Incaica. Facultad de Filosofía y Humanidades, Universidad Nacional de Córdoba, Córdova.

Le Paige, G. 1965. San Pedro de Atacama y su zona (14 temas). Anales de la Universidad del Norte $\mathrm{N}^{\circ} 4$, Antofagasta.

Llagostera, A. 2006. Contextualización e iconografía de las tabletas psicotrópicas Tiwanaku de San Pedro de Atacama. Chungara Revista de Antropología Chilena 38:83-111.

Manzanilla, L. and E. Woodard 1990. Restos humanos asociados a la pirámide de Akapana (Tiwanaku, Bolivia). Latin American Antiquity 1:133-149.

Metropolitan Museum of Art, Nueva York http://www.metmuseum. org/art/collection/search/310552 (April 15, 2013).

Mostny, G. 1957. La momia del cerro El Plomo. Boletín del Museo Nacional de Historia Natural 27 (1), Santiago.

Montell, G. 1929. Dress and Ornaments in Ancient Peru. Göteborg, Oxford University Press, London.

Murra, J. 1962. Cloth and its function in the Inka State. American Anthropologist 64:710-728.

Murra, J. 1993. Las funciones del tejido andino en diversos contextos sociales y políticos. In Arte Mayor de los Andes, pp. 9-19. Catálogo de exhibición del Museo Chileno de Arte Precolombino, Santiago.

Murúa, fray M. de 2004 [1590]. Códice Murúa: Historia y genealogía de los reyes incas del Perú del padre mercedario Fray Martín de Murúa: códice Galvin / estudio de J. Ossio. Testimonio Compañía Editorial, 2 vols, illustrations. Facsimile reproduction of the manuscript of 1590 (the original belonging to the private collection of Sean Galvin), Madrid.

Murúa, fray M. de 1946 [1590]. Historia del Origen y Genealogía Real de los Reyes Incas del Perú, edited by C. Bayle s.j. Instituto Santo Toribio de Mogrovejo, Madrid.

Murúa, fray M. de 1962 [1611]. Historia General del Perú, Origen y Descendencia de los Incas. Edición del Instituto Gonzalo Fernández de Oviedo, vol. 1; Madrid.

Platt, T. 2015. Refounding the House. Time, politics, and metallogenesis in a Colonial Aymara coat of arms. In The Measure and Meaning of Time In Mesoamerica and The Andes, edited by A.F. Aveni, pp. 239-273. Dumbarton Oaks Research Library and Collection, Washington, D.C.

Ponce Sanginés, C. 1981. Tiwanaku: Espacio, Tiempo y Cultura. Ensayo de Síntesis Arqueológica. Editorial Los Amigos del Libro, La Paz, Cochabamba.

Posnansky, A. 1945. Tiahuanaco. La Cuna del Hombre Americano. Volume I. Editor, J.J. Augustin, New York.

Ramos Gavilán, fray A. 1976 [1621]. Historia de Nuestra Señora de Copacabana. Academia Boliviana de la Historia, La Paz.

Reinhard, J. 1991. Tiwanaku: ensayo sobre su cosmovisión. Revista Pumapunku 2:82-97.

Reinhard, J. and M.C. Ceruti 2000. Investigaciones Arqueológicas en el Volcán Llullaillaco. Complejo Ceremonial Incaico de Alta Montaña. Universidad Católica de Salta, Salta. 
Trigo, D. and R. Hidalgo 2009. La relación iconográfica de los pies, piernas y cabezas en Tiwanaku y Huari: el caso de los decapitadores y sus coronas durante el Horizonte Medio. Actas de la XXIII Reunión Anual de Etnología, Tomo 1, pp. 3-13, Museo Nacional de Etnografía y Folklore, La Paz.

Trigo, D. and R. Hidalgo 2012. Tiwanaku-Huari: Los miembros inferiores y sus representaciones en las ofrendas del Horizonte Medio. CIMA, La Paz.
Verano, J. 2013. Excavation and analysis of human skeletal remains from a new dedicatory offering at Tiwanaku. In Advances in Titicaca Basin Archaeology-2, edited by A. Vranich and A.R. Levine. Monograph 77, pp. 167-180. Cotsen Institute of Archaeology, University of California, Los Angeles.

Villanueva, J. 2007. Las escudillas del Rasgo 1 en la isla de Pariti: interpretación y consideraciones desde un enfoque iconográfico. Chachapuma-Revista de Arqueología Boliviana 1:53-63. CIMA, La Paz.

\section{Notes}

1 This article was presented as a paper at the International Meeting on Archaeology and Ethnohistory in the Andes and lowlands. Complementary dilemmas and viewpoints. Homage to Teresa Gisbert, Verónica Cereceda and Waldemar Espinoza, Cochabamba, 24-29 August 2015.

2 "The tassel (royal insignia, which he always wore instead of a crown or diadem) was called maxcapaycha; it was red and made of the finest wool, four fingers wide and one thick; he wore it sewn into his llauto, hanging in the middle of his forehead, and it hung down to his eyebrows; the top half of this tassel was threaded in very thin threads through tubular gold beads, and the wool which entered was twisted and braided; and below the gold beads where it fell over his forehead it was neither twisted nor braided" (Cobo 1653:139). See also Larrea 1960.

3 Here we must mention specimens recorded from Playa Miller 2 (excated by Mostny 1943, Museo Nacional de Historia Natural, Santiago; Horta 2010), from Camarones 9 (excavated by P. Dauelsberg and V. Standen in 1988, conserved in Museo Arqueológico San Miguel de Azapa of Universidad de Tarapacá), and from Ilo, Moquegua (Castillo 2008), in the Western Valleys; the Museo de Metales Preciosos Precolombinos in La Paz also contains a large collection of similar silver and gold frontal adornments, although unfortunately their provenance is unknown.

4 At this point we must remember the words of Guamán Poma de Ayala, who says that "to the huaca of Titi Caca they sacrificed much gold and silver and clothing and twenty two-year-old children", in other words it would have acted as principal huaca which received the main offering, including human sacrifice or capacocha (Guamán Poma de Ayala, Felipe 1980 [1615]).

5 As it was named by Arriaga (1621).

6 Here I highlight some of the cases of escudillas published by Villanueva (2007: Figures 9, 15, 16, 17), and by Korpisaari and Parssinen (2011: Figures 30, 32), in which felines and avians are appreciated with this ornament on the neck. It draws attention to the fact that it is the feline which is most often associated with the hanging ornament chin, not the bird.

7 The presence of legs (or body parts) cut, forming the headdress of the Sacrificador Tiwanaku or Huari, had already been observed by other researchers, who have highlighted the symbolism of that association (Couture y Sampeck 2013; Llagostera 2006; Trigo e Hidalgo 2012).

8 See Plate 147: [Topa Amaro Inga] "conquered and killed and put out the eyes of his enemies, the principal Colla Suyo indians”. Plate 171: The fourteenth captain, Malco Castilla
Pari, Colla Suyo. Plate 250: July, month of inspection of the land, land distribution, the ceremony directed by uallauiza, "high priest", who presents the sacrifice as he is the incaised Colla shaman. Plate 272: "Idols and waqas of the Collasuyos, Uillca Nota". Plate 295: burials of the Collasuyos. Plate 326: "The festival of the Colla Suyos; they sing and dance from Cusco. The principal curaca says: "Quirquiscatanmallco...". Moreover, in the following cases it should be noted that a difference is observed in the type of headdress exhibited by these characters (Plate $153,279,505,620,767,794)$. They also are individuals of high rank, but his identity is not colla, but on the contrary, aymarae. This difference is enhanced by the fact that the headdress in these images is composed of a thick wreath with superimposed discs, on the top with two or three appendices, which could correspond to flowers or feathers. None of this characterized the headdress of Colla people. Guamán Poma says membership of some of these individuals as inhabitants of the province of Aymaraes, without giving details. To clarify this situation, it is something that is beyond the scope of this work. See Plate 153: [Auqui Topa Inga Yupanqui] "was a valiant captain who killed very many indians and captains and principals". Plate 279: high priests, valla viza, laica, ити, "the great sorcerer who was there". Plate 505: the Corregidor drinks with "low people", but all the same proposes the following toast to the tribute-paying indian "A toast [...], lord curaca". Plate 620: The mestizo offspring of parish priests being taken away to Lima. Plate 767: "Chiara, of the people of Muchuca, chunkakamachikuq, chief of ten tribute-paying indians". Plate 794: "Principals. Don Carlos Catura and his son, don Felipe Guayna Catura, don Juan Usco Paniura”.

9 See Horta 2011a and b.

10 At this point I differ from Platt's interpretation that the figure represented in the crest of the shield is Fernando Ayra de Ariutu's mother, doña Úrsula Ayra Kanchi Hanq'u Tutumpi, rather than the applicant himself. For various reasons I consider that it is a masculine and not a feminine figure; for one thing the figure portrayed wears the long hair of altiplano noblemen (see Guamán Poma's drawings in Figures 4a, 4b, 4d, 5a, 5c, 5d, 6a, 6b, 8, 9 and 22 of this article); for another there is information from chronicles that only Inca nobles wore short hair down to the ears, a privilege forbidden to other ethnic groups. The Proof mentions that Inca Wayna Capac made a present of an uncu or "shirt of gold discs", to Úrsula's grandmother. This was the fundamental piece of pre-Hispanic male clothing, since women used the acsu, a dress which came 
down to their calves, fixed at the shoulder by tupus. It is therefore improbable that a woman like doña Úrsula would appear in the coat-of-arms wearing male clothing, even if the item was an heirloom. Furthermore, the chroniclers mention the prestigious present of uncus cumbis made by Inca rulers to curacas of other ethnic groups, in other words exchanges between high-ranking male personages (Murra 1962, 1993). 